\title{
From rubbish to cultural identity Making archaeology relevant for the contemporary community
}

\author{
IRMAWATI MARWOTO
}

\begin{abstract}
Archaeological relevance for the present has become an important issue in the world of archaeology. This paper aims to examine how the biography of artefacts of pottery fragments from the old Banten site, the site of Banten Sultanate of the sixteenth century AD, became a marker of the cultural identity of Banten people today. These pottery fragments were studied using Michael Thompson's rubbish theory (1979), which observes how the value of objects shifts from transient to rubbish to durable. Using the rubbish theory, archaeological practices that have only been aimed at scientific purposes can be useful for the people of Banten today. This paper will also discuss how people who have been ignored become an important part of archaeological practice and how archaeology can have an economic impact on today's society.

KEYWORDS

Relevant; rubbish; cultural identity; Banten Lama; pottery; community.
\end{abstract}

\section{INTRODUCTION}

The question of archaeological relevance for today's society has long been a debate in the world of archaeology. People ask a lot of questions about archaeological practice, about what the benefits and relevance of archaeology are to society. Various debates on this issue have arisen among archaeologists themselves regarding, as Veerasamy Selvakumar puts it, how to justify the fact that archaeology has benefits for the society (2010: 468). In the academic world, archaeology is regarded as a very special craft that cannot be linked

IRMAWATI MARWOTO (1956) is currently an instructor in the Department of Archaeology, Faculty of Humanities, Universitas Indonesia. She received her PhD from Universitas Indonesia with a dissertation titled Decorative arts on the structures of North Coast Java in the fifteenth-seventeenth centuries; A question of Islamic markers (2003). Her publications include the article "Archaeology for whose interpretation? Finding space for alternative archaeology in Indonesia", Public History Review 19 (2012: 111-119). Her research interests focus on archaeology of Islamic art, material culture, and museology. Irmawati Marwoto may be contacted at: irmawati_marwoto@yahoo.com.

(C) 2019 Faculty of Humanities, Universitas Indonesia

IRMAWATI MARWOTO | DOI: 10.17510/wacana.v20i2.678. 
directly to the needs of human beings, unlike medicine and economics for example. However, according to Selvakumar, the usefulness of archaeological knowledge can be linked to education in archaeological sites; monuments and museums can help the younger generation appreciate the cultures of the past. In addition, archaeology can help in the search for the cultural roots of a person or a group of people. It can even become a tool to create the identity of a nation (Selvakumar 2010: 472-474; Trigger 2006: 543-544). Furthermore, Joe Flatman (2012: 291) argues that archaeology must play a role in the twentyfirst century global society by contributing to problems such as climate change and limited or scarce life-sustaining resources.

In Indonesia, very few archaeologists have joined this debate. They tend to take on the attitude of business as usual. This paper discusses how heritage, in this case fragments of pottery from archaeological excavations that have become part of a museum collection, can benefit the people of Banten today. The heritage referred to in this case are artefacts in the form of pottery fragments resulting from archaeological excavations on the site of the Sultan of Banten's royal palace that have become part of the collection of the Banten Museum. As stated by Peter Howard (2003), heritage can be anything that is desired to be preserved and conveyed to future generations (2003: 6). Likewise, Francis P. McManamon and Alf Hatton (2000: 3-4) state that what is meant by heritage is not only limited to archaeological sites or man-made objects produced from archaeological excavations as relics of the past but also include historical buildings that are on the ground including vernacular, museum collections, living traditions and natural landscape.

This paper explains how the intangible tradition, namely the knowledge of ornaments used by the people of Banten in the past, was rediscovered through tangible material culture. According to UNESCO's definition of 2003 (in Rudolff 2006: 29), intangible cultural heritage is a practice, representation, expression, knowledge, or skill that is recognized as part of cultural heritage of a community. As stated by Mounir Bouchenaki (in Rudolff 2006: 29), intangible heritage must be seen as a large framework wherein tangible heritage is formed. This was supported by museum experts attending a meeting at Oegstgeest in 2004 who stated that each artefact is formed through intangible heritage (Bouchenaki in Rudolff 2006: 29).

In terms of benefits for the general public, archaeology is always associated with Cultural Resource Management (CRM). It is as though archaeology could only be useful for society through CRM. Archaeology seems to stand on its own, remaining true to its beginnings as mainstream archaeology that is only fixated on data collection.

This paper will discuss how my research using action-based research approaches could update and complement the development of archaeological knowledge related to identity in the local context. For this, the rubbish theory of Michael Thompson (1979) has inspired me to show how fragments of pottery can become part of a cultural identity. This study will show how the journey of an archaeological object that began from the results of an excavation can 
become a marker of cultural identity of today's community. The movement or journey of an object, which is seen as its social life deriving from its past heritage and experienced a transformation and a change in function and significance, is associated with the benefits of archaeology for today's society.

\section{THOMSON'S RUBBISH THEORY}

According to Thompson's theory on rubbish (1979), the value of an object experiences a journey, from transient, rubbish, to durable; see the application of the theory in my research in Figure 1.

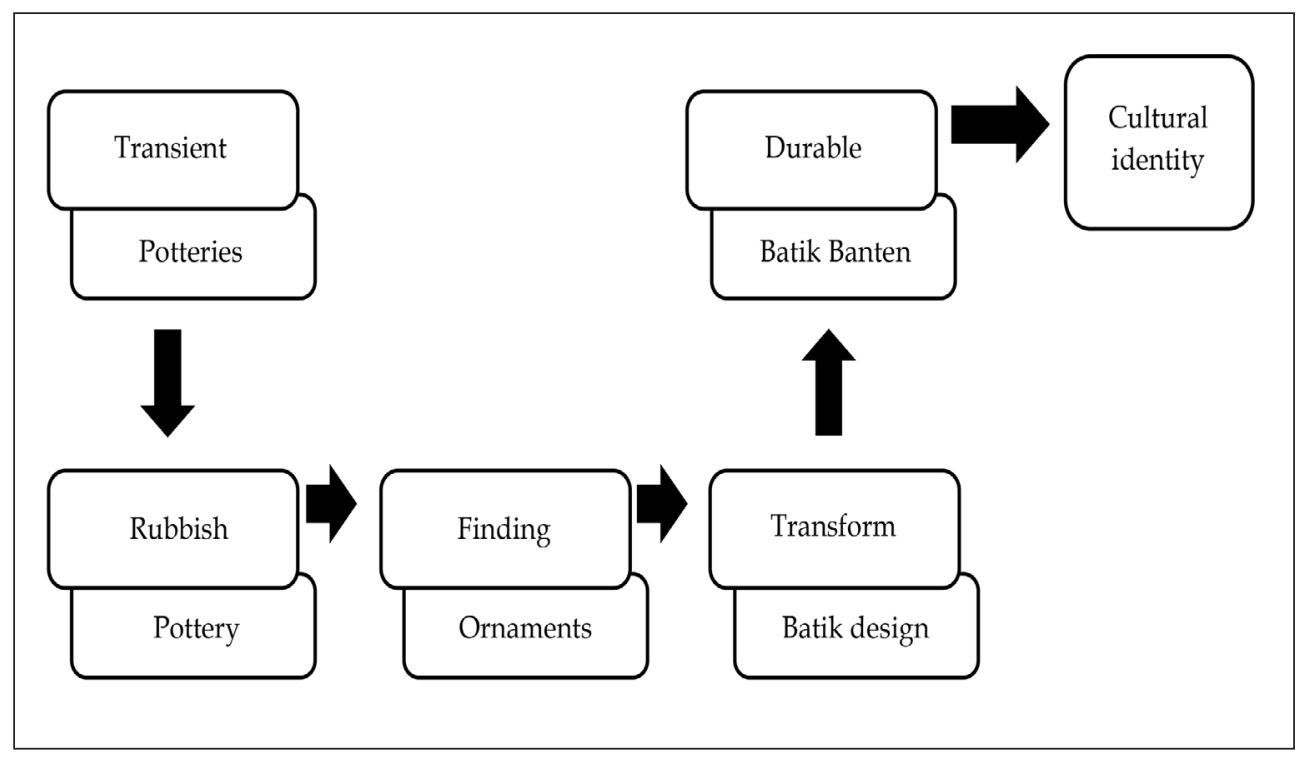

Figure 1. From rubbish to durable based on Thompson (1979: 10).

In Thompson's view, a thing or object moves between two states, namely transient and durable. An object falls into the transient category if it experiences a decline in value and has a limited lifetime. On the other hand, objects that fall into the durable category experience an increase in value and have an unlimited lifetime. How we treat these objects is also different, for example, we will store or display objects that we consider valuable, while we will discard objects that we do not consider valuable. There is another category of objects called rubbish. Objects in this category do not have any value or are said to have zero value and do not fall into either transient or durable categories (Thompson 1979: 270-271; Parsons 2008: 390). Rubbish is a collection of objects we do not want, things that are dirty, and when we see them we look away as we do not want to see and talk about them. These rubbish objects push our awareness to think about how these things should be laid out (Carman 2010: 79). Further, Thompson explains that ideally an object goes on a journey that moves slowly from transient to zero value called rubbish. Objects that are durable cannot be transferred to the transient 
material category because durable objects should persist in time and always experience an increase in value over time. Similarly, objects with rubbish value cannot be transferred to the transient category because rubbish has zero value (Thompson 1979: 272-273).

However, Thompson's theory has its limitations. It does not always happen that way. Things that are durable cannot always be transferred to the category of transient objects or rubbish. This can happen when a durable object is withdrawn from circulation or is corroded or broken into pieces or stolen. Similarly, objects in the rubbish category can be transferred to the transient category, although this is rare. A used car dealer can delay the transfer process from transient to rubbish (Thompson 1979: 273).

The Thompson theory, also known as the "rubbish triangle", is used in this study but with the addition of one category, that is cultural identity following the durable category. This category becomes important after the object undergoes a journey of life from transient to rubbish and from rubbish to durable, and from being durable objects into markers cultural identity. In this study, the rubbish theory serves as a conceptual framework and a model that explains this process of turning the rubbish of the past into something of great importance for the present.

THE SOCIAL LIFE OF A POTSHERD FOUND IN THE ARCHAEOLOGICAL SITE OF OLD BANTEN

Daniel Miller (2002) in his article "Artefacts and the meaning of things" states that like human beings, things also have values such as longevity and transience. Transience means that things or objects in their interactions with humans have a social life because the meanings given to objects and those given to humans undergo the same process (Miller 2002: 409). In addition to Miller, Marcel Mauss (1954), as he demonstrates in his research on the Melanesian society in the Pacific region, does not contradict what Miller calls a dualistic opposition between humans and objects. Objects in this case are "gifts" and gifts are something that must be returned because they contain something inalienable. The objects are attributes of the person who gives them, and the objects are seen as markers of relation between the human beings associated with the obligation to give and return the "gifts". Further, Mauss also asserts that humans can be exchanged as gifts and gifts can be seen as a marker of the status of the one giving them (Miller 2002: 416). Arjun Appadurai (1986 in Longhurst 2008: 135) contends that material objects have a social life so that the biography of things can be traced through the usefulness and meaning of those objects that change with time and space.

In archaeology, the view that no longer distinguishes between material culture and the mind is called symmetrical archaeology, which considers things and people to be fundamentally inseparable (Gonzales-Ruibal 2014: 4-7). In Igor Kopytoff's view, both humans and objects have a biography as a commodity. Commodity, according to Kopytoff (1986: 64-69), is an object that has a use value that can be exchanged in a transaction with a buyer. In 
brief, it can be said that anything that can be bought with money at a certain time is called a commodity. In its journey as a commodity, objects have the potential to oppose commoditization, which is culture. Through culture, there can be a singularization with which a commodity is pulled out or dismissed from its status as a commodity. The sacralization of European ceramic mugs brought to Africa by the Portuguese by the Zairan tribe is an example of how a commodity was withdrawn from its space. In addition to sacralization, restrictions can also stop the commoditization of objects. In modern society, singularization can occur with so-called collectible objects (Kopytoff 1986: 73).

Life history in archaeology was done by Cornelius Holtorf (2002) in studying a megalithic monument in Mecklenburg-Vorpommern, Germany. He observed how relationships between the life of objects and the life of humans came into being and how the objects in circulation help explain how humans become part of things and objects part of humans. He also assumes that the social life or life history of an object starts from the moment an object is made and ends when it is discarded. The thing ends up being rubbish, ruins, or mummies. Nevertheless, there is an alternative life history of objects that does not always end when they are discarded but continues to this day as long as there still are activities such as discovery, recovery, analysis, interpretation, archiving, and display (Holtorf 2002: 53).

Kopytoff (1986) refers to the journey of living objects as the biography of things. This and what has been explained above has inspired me to see how the fragments of Banten pottery experienced the journey of life, starting with the moment they were produced during the Sultanate of Banten to the manner in which they provide benefits for the people of Banten today.

\section{FROM TRANSIENT TO RUBBISH}

Until now, Old Banten is known as the area containing archaeological remains of the Sultanate of Banten, which was in power from the fifteenth to the eighteenth centuries. In its heyday a few centuries ago, the Sultanate of Banten was known as an emporium, a port city that functioned as a place for stockpiling merchandise, and a place of international trade. Based on written sources (Kathirithamby-Wells 1990; Leur 1955: 139; Reid 1993: 65-66; Untoro 1998), there were at least nineteen foreign merchants in addition to merchants from various regions in the archipelago who turned the place into a bustling trade area. The merchants consisted of wholesalers and retailers. In general, these merchants carried various commodities produced in their countries or regions of origins to be traded in Banten. Among the big foreign merchants who played an active role in the trade scene were merchants from China, Arabia, the Netherlands, and England. From China, they brought ceramics, metal appliances, and various food items. Arabs were known for their variety of perfumes, clothing, and gemstones. Dutch and British merchants were known to be merchants who liked to buy more than to sell. They looked for and bought spices to be brought back to their countries and to be sold there. The Sultanate of Banten was also known as a place that produced pepper 
(Piper nigrum), which at that time was much sought for mainly by European traders. The appeal of pepper is what seems to have brought the Dutch and British merchants to play an active role in trade in Banten. The Dutch and British even established trading offices in Banten.

Archaeological research that has been carried out in the Old Banten to date has found a variety of artefacts: tens of thousands of ceramic fragments, the remnants of tools made of metal, coins, and hundreds of thousands of clay fragments. The results of the analysis of the above findings revealed that part of the ceramics apparently came from Japan (in the seventeenth to eighteenth centuries), and some eighteenth century ceramics came from Europe. Metal goods made of gold, iron, copper, bronze, and tin were also found. Equipment made of such metals includes spoons, forks, knifes, jewellery, keys, guns, bells, chisels, mirrors, horseshoes, hinges, lamps, bullets, rings, bells, buttons, and wire.

Material culture pottery made of clay was found in the hundreds of thousands, spread over almost every inch of land throughout the Old Banten site. The huge number of clay objects shows that clay played an important role in people's lives during the Sultanate of Banten. A toponymical study also shows the existence of a village called Panjunan. According to the Authorized Indonesian Dictionary, Panjunan means a place to make pottery. Currently, the place's name has changed to Sukadiri. The results of archaeological excavation research at Sukadiri site proved that Panjunan was formerly the place where clay pottery was made because potters' wheels and anvils that were important equipment in making pottery from clay were found. Apart from that, decorative moulds were also discovered.

The results of archaeological analysis of the thousands of fired clay fragments show that the manufacture of clay goods was very popular during the Sultanate of Banten. Such findings were also found in pre-history sites that go back thousands of years on other sites in Indonesia and other countries. Human wisdom that allows human beings to use their environmental resources, in this case clay, to support their life results in cultural products that are universal. Because objects made of clay were often found all around Indonesia, clay ware is known by different names. The decade of the 1970s was known for its local ceramics that are distinguished from foreign ceramics, which are made of kaolin clay. In the 1990s, Ingrid H.E. Pojoh (1990) mentioned that these local ceramics are called terracotta, and Bambang Sumadio (1990), referring to the technique of making terracota, calls it keramik tanpa glasir or glazeless ceramics. Santoso Soegondho (1993) in his dissertation calls it keramik tanah liat or clay ceramics, and in 1995 he used the word gerabah, which is a Javanese word meaning table ware made from clay. In addition, the entry tembikar appears in Kamus bahasa Indonesia (2008: 1431) meaning goods made of fired clay. The diverse words used to describe the same thing shows that the role of fired clay goods in human life in Banten is very important, especially in the past. Therefore, it is not extravagant for this research to focus on pottery at the Old Banten site because in addition to huge numbers of pottery fragments 
that were found, those objects have their own uniqueness, especially in the form of the unique ornaments or designs on them.

Old Banten as the centre of the kingdom of Banten has left us various forms of cultural heritage, one of which is pottery. There are two pottery craft centres that played a big role in Banten Lama's (or Old Banten's) culture: Sukadiri and Panjunan. Sukadiri is located 300 meters southwest of the Surosowan palace or southwest of the Grand Mosque, whereas Panjunan is northeast of the Grand Mosque complex (Sudjana 1978: 19-20). The pottery from Sukadiri and Panjunan was distributed throughout Banten Lama, but in Surosowan more Sukadiri pottery was found than the Panjunan pottery. It is estimated that the quality of the Sukadiri pottery was better than that of the Panjunan pottery, and the palace of Sukadiri naturally preferred good quality. The Panjunan pottery was more common in Pamarican than Sukadiri pottery. Very likely this is because Sukadiri used to be the place where ordinary people lived. In addition, Panjunan was located outside the city walls while Sukadiri was within those walls (Syahril 1997: 124-128). Pottery fragments at the Banten museum are an important heritage of the society of Banten today. The existence and excavation of these two sites, namely the Sukadiri and the Panjunan sites, show that during the Banten Sultanate from the fifteenth to eighteenth centuries, there were two large pottery manufacturing centres that supplied the needs of the palace, among others. This means that the Banten people in the past already had the skills and knowledge of pottery making and produced various forms and ornaments no longer known by Banten people today.

Based on the results of research on approximately 300 fragments of pottery found in the Old Banten museum site, 87 ornaments were identified consisting of 71 geometric ornaments, 5 vines ornaments, 10 zoomorphic ornaments, and 1 anthropomorphic ornament. The research results demonstrate that Banten pottery used a lot more geometric ornaments compared to zoomorphic or anthropomorphic ornaments (see Table 1 and the appendix). This could be related to the fact that Islamic art avoids taswir or the depiction of living beings (Marwoto-Johan 2012b: 5-22).

Many techniques of making ornaments on pottery are seen, for example, etching, impressing using tools, attaching, carving, and pinching techniques (Marwoto-Johan 2012b: 22). It is unfortunate that the labels of this collection of pottery fragments have been lost making it difficult to carry out further research.

What the archaeologists found in Banten are fragments of pottery produced in Old Banten. Following Thompson (1979), this is how objects with transient value become rubbish. The archaeological research on the Old Banten site never involved the community of "Old Bantam". Archaeologists did research that was solely for their own benefit. The community was not aware that what archaeologists excavated was an important source of knowledge, not only of their past but something that is relevant for their life in the present. 
Wacana Vol. 20 No. 2 (2019)

\begin{tabular}{|c|c|c|c|c|}
\hline No & Motif & Basic forms & Motif shape & Examples \\
\hline \multirow[t]{28}{*}{1} & \multirow[t]{28}{*}{ Geometrical } & \multirow[t]{3}{*}{ Circles } & Flower & $\begin{array}{l}\text { (1) (2) (3) (4) } \\
(5)(6)\end{array}$ \\
\hline & & & Circle & $(7)(8)(9)(10)$ \\
\hline & & & Half circle & $(11)$ \\
\hline & & \multirow[t]{5}{*}{ Squares } & Flower & $(12)$ \\
\hline & & & Four curves & (13) \\
\hline & & & Eight curves & $(14)$ \\
\hline & & & Eight triangles and circles & $(15)$ \\
\hline & & & Square with protrusions & $(16)$ \\
\hline & & \multirow[t]{7}{*}{ Rhombuses } & Flower & $(17)(18)(19)$ \\
\hline & & & \begin{tabular}{|l|} 
Eight curves \\
\end{tabular} & $(20)$ \\
\hline & & & Twelve curves & $(21)$ \\
\hline & & & $\begin{array}{l}\text { Twelve angles with } \\
\text { circles }\end{array}$ & (22) \\
\hline & & & Three- tiered rhombus & $(23)$ \\
\hline & & & $\begin{array}{l}\text { Rhombuses arranged } \\
\text { vertically }\end{array}$ & (24) \\
\hline & & & Leaves with pointed tips & $(25)$ \\
\hline & & \multirow[t]{8}{*}{ Triangles } & $\begin{array}{l}\text { Triangle without a } \\
\text { frame }\end{array}$ & $\begin{array}{l}(26)(27)(28) \\
(29)\end{array}$ \\
\hline & & & $\begin{array}{l}\text { Serrated triangle with a } \\
\text { frame }\end{array}$ & $(30)(31)$ \\
\hline & & & $\begin{array}{l}\text { Serrated triangle split } \\
\text { in two }\end{array}$ & $(32)(33)$ \\
\hline & & & $\begin{array}{l}\text { Serrated triangle with } \\
\text { curved bottom }\end{array}$ & $\begin{array}{l}(34)(35)(36) \\
(37)\end{array}$ \\
\hline & & & Flower shaped triangle & $(38)(39)$ \\
\hline & & & $\begin{array}{l}\text { Blunt triangle with a } \\
\text { prominent curved frame }\end{array}$ & $(40)$ \\
\hline & & & $\begin{array}{l}\text { Triangle with curly } \\
\text { sides }\end{array}$ & $(41)(42)(43)$ \\
\hline & & & Leaf-shaped triangle & $(44)(45)$ \\
\hline & & Serrated & Serrated Longitudinally & $(46)(47)$ \\
\hline & & \multirow[t]{2}{*}{ Leaves } & Tapering leaves & $(48)$ \\
\hline & & & Leaves with blunt tips & $(49)$ \\
\hline & & $\begin{array}{l}\text { A collection } \\
\text { of squares }\end{array}$ & $\begin{array}{l}\text { A square consisting of } \\
\text { small squares }\end{array}$ & (50) \\
\hline & & Curves & One-sided curves & $(51)$ \\
\hline
\end{tabular}




\begin{tabular}{|c|c|c|c|c|}
\hline No & Motif & Basic forms & Motif shape & Examples \\
\hline \multirow[t]{5}{*}{2} & \multirow[t]{5}{*}{ Tendrils } & \multirow{2}{*}{$\begin{array}{l}\text { Tendrils } \\
\text { without } \\
\text { flower }\end{array}$} & $\begin{array}{l}\text { Tendrils opposite each } \\
\text { other }\end{array}$ & $(52)$ \\
\hline & & & $\begin{array}{l}\text { Tendrils protruding to } \\
\text { the side }\end{array}$ & (53) \\
\hline & & \multirow{3}{*}{$\begin{array}{l}\text { Tendrils } \\
\text { with } \\
\text { flowers }\end{array}$} & $\begin{array}{l}\text { Tendrils with four } \\
\text { petalled flowers }\end{array}$ & $(54)$ \\
\hline & & & $\begin{array}{l}\text { Tendrils protruding } \\
\text { from the left and right } \\
\text { sides of the flower }\end{array}$ & (55) \\
\hline & & & $\begin{array}{l}\text { Tendrils protruding } \\
\text { under the flower }\end{array}$ & $(56)$ \\
\hline \multirow[t]{10}{*}{3} & \multirow[t]{10}{*}{ Zoomorphic } & \multirow[t]{7}{*}{ Head } & $\begin{array}{l}\text { Head 1: like a snake's } \\
\text { head, with scales }\end{array}$ & $(57)$ \\
\hline & & & $\begin{array}{l}\text { Head 2: elongated face, } \\
\text { with open mouth }\end{array}$ & $(58)$ \\
\hline & & & $\begin{array}{l}\text { Head 3: Face with } \\
\text { big eyes, open mouth } \\
\text { showing teeth }\end{array}$ & $(59)$ \\
\hline & & & $\begin{array}{l}\text { Head 4: Like a snake's } \\
\text { head but with a human } \\
\text { nose }\end{array}$ & $(60)$ \\
\hline & & & $\begin{array}{l}\text { Head 5: With a crown, } \\
\text { nose and mouth broken }\end{array}$ & $(61)$ \\
\hline & & & $\begin{array}{l}\text { Head 6: snake- like head } \\
\text { as it has scales }\end{array}$ & (62) \\
\hline & & & $\begin{array}{l}\text { Head 7: a bird or } \\
\text { chicken-like head as it } \\
\text { has a beak like a bird } \\
\end{array}$ & (63) \\
\hline & & \multirow[t]{2}{*}{ Body } & Bird's body & $(64)$ \\
\hline & & & Seashell & $(65)$ \\
\hline & & $\begin{array}{l}\text { Parts of the } \\
\text { head and } \\
\text { body }\end{array}$ & Water buffalo & $(66)$ \\
\hline 4 & Anthropomorphic & Body & Body without arms & $(67)$ \\
\hline
\end{tabular}

Table 1. The Banten Museum Collection of Banten Pottery Ornaments. The numbers refer to the illustrations in the appendix.

SCAVENGING THE RUBBISH

What the archaeologists came across in Banten could be considered as waste or rubbish in the form of useless broken pieces of pottery. Rubbish or waste is not a static object with a definite value but in its circulation. It changes following the different regimes of value, from that which is considered to be 
useless or dirty, that which is no longer wanted, to that which is considered very useful (Reno 2009: 29-30). The thing that makes rubbish interesting is that it originates as a transient object which then becomes rubbish that can reappear. This has challenged our assumptions about rubbish and thus we need to re-classify rubbish (Thompson 1979: 45, in John Carman 2010).

What I did was also scavenging rubbish or waste in the Banten Lama Museum Site. After excavating in Banten Lama from 1975 to 2000, I returned again to Banten Lama in 2012 to look back at the possibilities of doing research again. What I found were mounds of broken pottery in the museum yard that had begun to be covered with soil. When I asked the museum officer about this, he explained those were the remnants of the excavation held since 1975 from the Palace of Surosowan Banten Lama site. He added that the museum no longer had the data about these pottery fragments. While scavenging the site, I started thinking about the opportunities I could get from this waste. It turned out that I was able to count and sort the broken pottery into 300 pieces consisting of various sizes, large, and small. After that, I collected the pieces of pottery that still had recognizable ornaments on them. From the 300 pieces of pottery, I collected 87 kinds of ornaments. The process of finding opportunities is what distinguishes an object that is useful from a mound of rubbish. This is what Joshua Reno (2009) refers to as interpretive practice individuation (Reno 2009: 34). In line with Joshua Reno's views (2009: 33), I could feel that this scavenging activity was a meaningful practice, because there were opportunities, anxieties, and also enjoyment when sorting and choosing various pieces of pottery from the pile left abandoned on the ground.

Inspired by the Rubbish model from Thompson, I managed to scavenge waste or rubbish that was no longer considered important by the museum on the Banten Site and see it as something that in my opinion was meaningful.

\section{TRANSFORMING THE INDIVIDUATION FINDING}

Transformation of an object is one way to revive a rubbish object. Transformation can also be an attempt to recreate a new function of an object or to create a new form. The re-creation of an object into a new object can change the value of an object (Parsons 2008: 392).

The result of interpretive practice individuation of the rubbish of the Banten pottery shards has produced 87 kinds of ornament that were then transformed into 20 different new design motifs. Each design was given the name of one of the sons and daughters of the Sultanate of Banten, as well as the names of important places mentioned in the history of Banten. The objective of doing this was to ensure that these names would become part of the collective memory of the Banten society today. These new designs were then shared with the people of Banten, and a batik producing community in the city of Serang, Banten, was selected so that they could apply the motifs of the Banten pottery to meet the interests of the today's community (see Figure 2, from Untoro et al. 2014). 

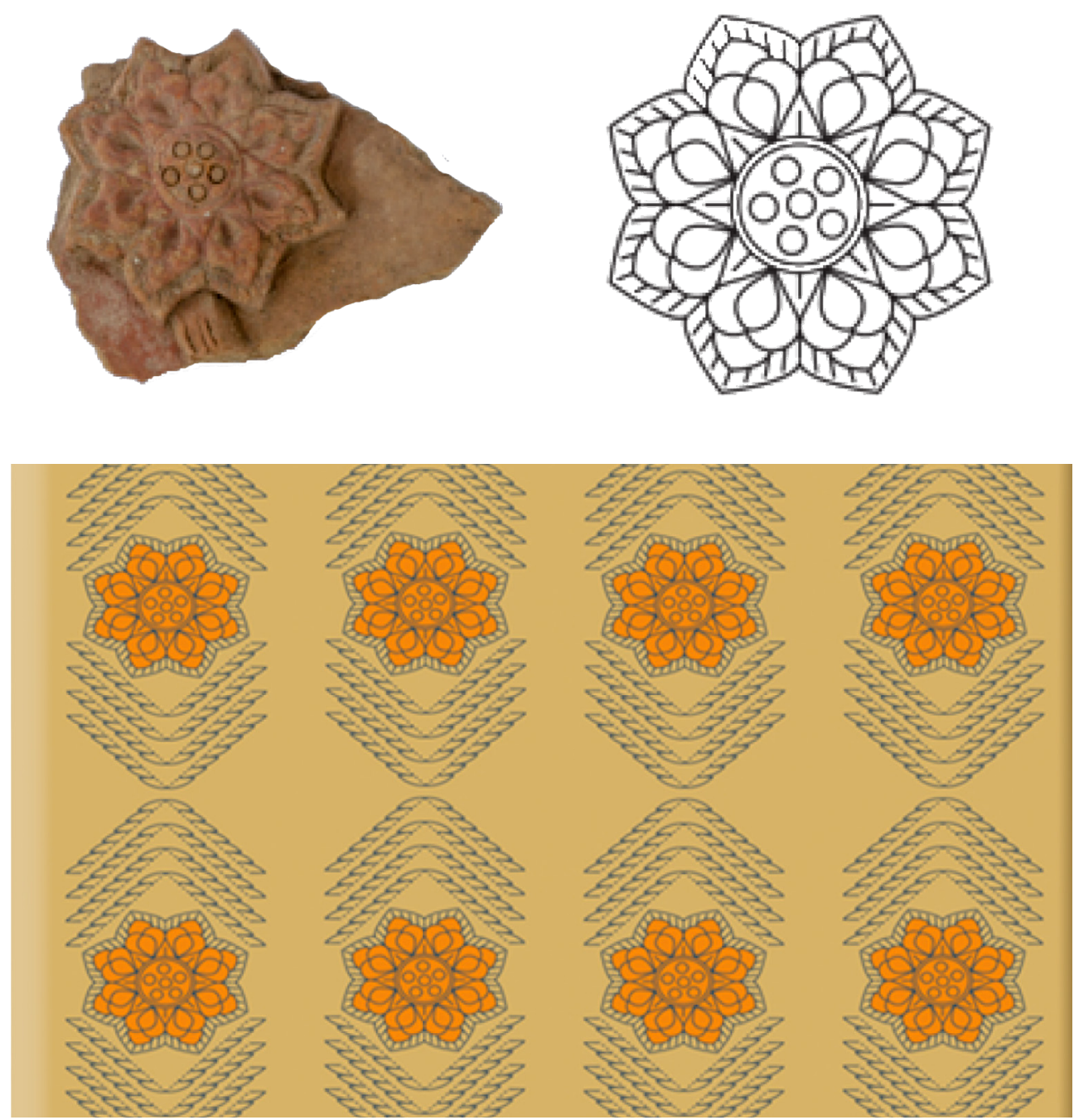

2a. Ratu Inten (The tenth daughter of Sultan Abdul Ma'ali) 

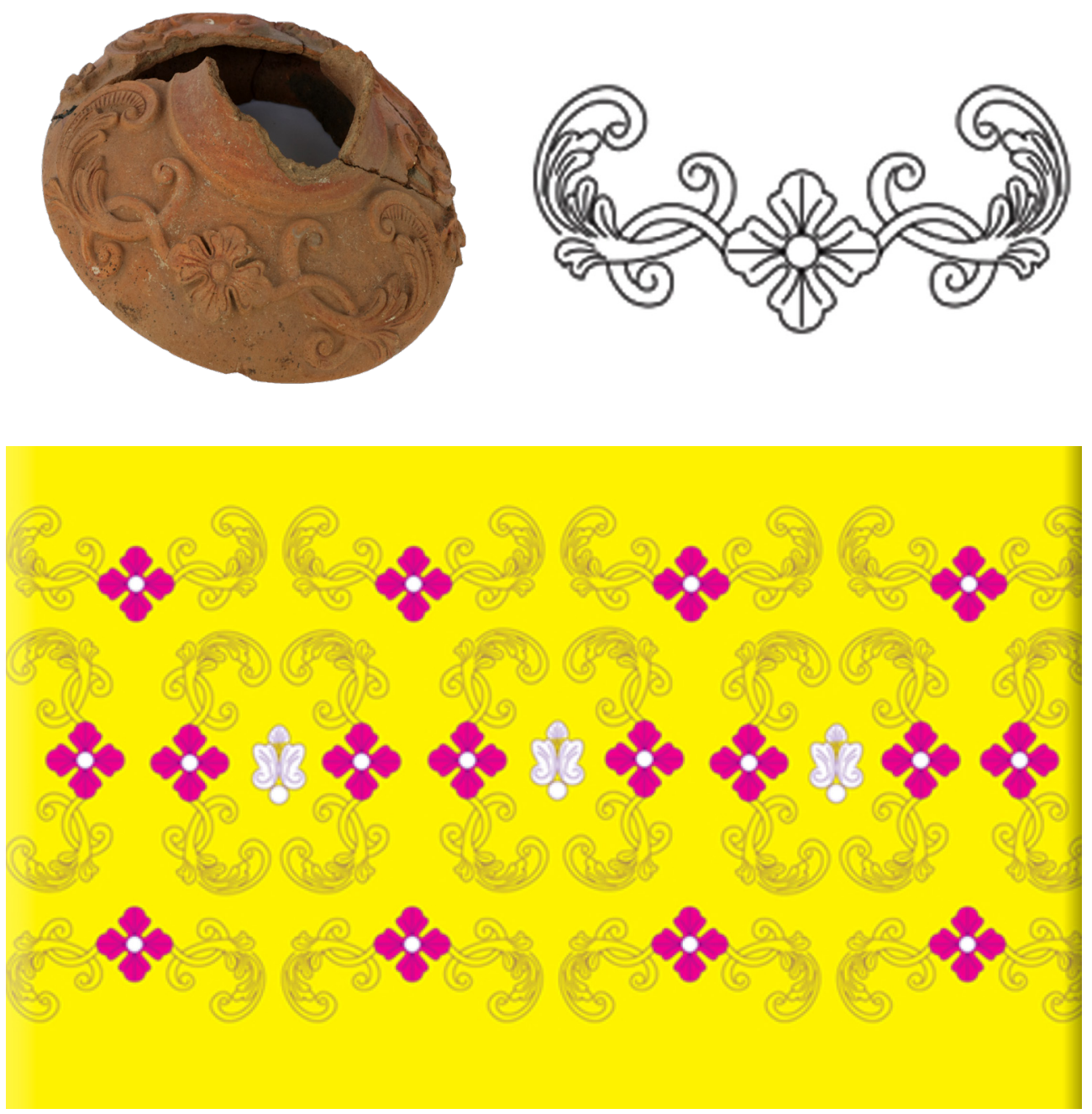

2b. Pangeran Turusmi (The youngest son of Syarif Hidayatullah)

Figure 2. Ornaments on the Banten pottery and new designs.

WORKING WITH COMMUNITIES FROM RUBBISH TO DURABLE

In the development of archaeology, it is no longer sufficient to consider the practice of archaeology as being solely for the sake of implementing scientific methods for collecting and interpreting data. As Barbara Little points out, archaeologists need to use their knowledge to educate, bond communities, and develop people's economy and pleasure (Little 2012: 1). Archaeologists in America have long recognized the need to involve the community in archaeological activities by taking into account the need to involve societies such as the descendants of the Native American or African societies in their research (Mullins 2004; McDavid 2004; Warner and Baldwin 2004). Working with communities is important because the community can provide insights for archaeological activities everywhere. 
The involvement of local communities in archaeological research is generally limited to acting as informants and wage workers. Archaeologists doing their research rarely convey the purpose and benefits of what they are doing to local communities either at the beginning or at the end of their research (Lane and Mapunda 2004: 22). In relation to archaeological research activities such as these, the archaeologists are the only ones who have the authority of knowledge, and all the results of the research activities are only for the benefit of academics (Marwoto-Johan 2012a). Collin Renfrew and Paul Bahn have also reminded archaeologists that they have an obligation to explain what they are doing and why to other researchers as well as the general public. Without doing this the archaeologists could be likened to treasure looters (Renfrew and Bahn 2000: 559).

Nick Merriman (2004) mentions two models that can be used to explain why the community should be involved in archaeological activities. Firstly, the deficit model that considers that the involvement of the community will provide an understanding of what archaeology is doing and with this understanding the community will support the activity. In this model, society is considered to require proper education to be able to appreciate archaeological research. The disadvantage of this model is that in reality there is much contestation and conflict in the heritage world so that it is necessary for education to provide people with tools to evaluate different things so that everyone can make their own conclusions. Secondly, the multiple perspective model sees that the purpose of involving the community in archaeology is to encourage self-realization and enrich their life, as well as to stimulate creativity and reflection. In this model, archaeologists must help the community to achieve their goals and no longer force them to follow an agenda (Merriman 2004: 5-7).

Holtorf (2007: 109) proposes three models: 1. the education model; 2. the public relations model; and 3 . the democratic model. The education model seeks to get as many people together as possible to observe the past and work of archaeologists in the same way as archaeological professionals. The public relations model believes archaeologists need to improve the archaeological image that the public have in order to gain social, economic and political support (Holtorf 2007: 114-119). In contrast to the above two models that see society as the subject of education and as a subject to influence, the democratic model sees that archaeologists should support, encourage, and enable everyone to freely develop their interest and passion for archaeology (Holtorf 2007: 119). The two models by Holtorf, namely the education model and public relations model, are an improvement of the Merriman's deficit model, while Holtorf's democratic model is equivalent to Merriman's multiple perspective model (Matsuda and Okamura 2011: 5).

These models show that there are four approaches to public archaeology, namely the educational approach and public relations approach, among others, which follow the approach of the deficit model. On the other hand, there are the pluralist approach and the critical approach that follow the approach of 
the multiple perspectives model. The deficit models see the public as objects that must be intervened in the sense that they must be educated, told and made interested, while the multiple perspective model sees the public as a subject that has the agency and interacted in the past in accordance with their beliefs, interests, and their own agenda (Matsuda 2016: 3-4). In their development, the four public archaeology approaches are shifting, which are the educational approach, the public relations approach, the pluralist approach, and the critical approach. This change, according to Matsuda and Okamura (2011), is in response to the demands of economic Neo-liberalism that emphasizes the free-market and pursues exchange values in every social activity. In this case, archaeology is no longer a barrier to economic development in the context of the preservation of the past (Matsuda 2016: 5). The three approaches, namely educational, public relations, and pluralist approaches can work together to answer the needs of today's society related to the urgency to strengthen the economy. Recent public archaeology studies place more emphasis on collaboration, sharing, and dialogue with various community groups to strengthen the usefulness of archaeology. On the other hand, the critical approach is not considered favourable because it opposes archaeology becoming the subject of economic markets (Matsuda 2016: 6). For the correspondence between the models and the approaches see Table 2.

\begin{tabular}{|c|c|c|c|c|}
\hline & \multicolumn{2}{|c|}{ More practice-oriented } & \multicolumn{2}{|c|}{ More theory-oriented } \\
\hline Merriman's & \multicolumn{2}{|c|}{ Deficit model } & \multicolumn{2}{|c|}{ Multiple perspective mode } \\
\hline $\begin{array}{l}\text { Holtorf's models } \\
\text { (2007) }\end{array}$ & $\begin{array}{l}\text { Education } \\
\text { model }\end{array}$ & $\begin{array}{l}\text { Public relations } \\
\text { model }\end{array}$ & \multicolumn{2}{|c|}{ Democratic model } \\
\hline $\begin{array}{l}\text { Four approaches } \\
\text { to public } \\
\text { archaeology }\end{array}$ & $\begin{array}{l}\text { Educational } \\
\text { approach }\end{array}$ & $\begin{array}{l}\text { Public relations } \\
\text { approach }\end{array}$ & $\begin{array}{l}\text { Pluralist } \\
\text { approach }\end{array}$ & \begin{tabular}{|l} 
Critical \\
approach
\end{tabular} \\
\hline
\end{tabular}

Table 2. Correspondence between Merriman's models, Holtorf's models, and the four approaches to public archaeology (Matsuda 2016:3).

The model used in this study comprises the last three approaches namely the educational, public relations, and pluralist approaches that see the community as a subject and also that archaeology can have an economic impact on today's society.

The steps that have been taken to transform the results of the Banten pottery shards research into new designs will be presented to the people of Banten in order that those designs can be applied for their benefit today. The next problem is deciding which Banten community should be involved in the collaboration and discussion of the ornamental designs on the Banten pottery. As stated by Richardson and Almansa-Sanchez (2016: 200), the public of archaeology can be the local communities or religious groups, tourism organizations, television viewers of historical events programs, etcetera. 
The community becomes an important part of public archaeology practice although in reality the archaeological community cannot be generalized. The important thing to do is to practice public archaeology so that it can play an ethical professional role (Richardson and Almansa-Sanchez 2016: 200).

Because this research produced ornamental motifs from pottery, the community selected was the batik community, who produce the traditional batik cloth using wax and dye. My research into the makers of batik cloth in Banten showed that they did not have any unique design and thus they are little known among the community. For that reason, collaboration was made with the makers of Banten batik to jointly create specific Banten batik motifs deriving from the motifs found when scavenging pottery shards on the grounds of the Banten Museum. In addition to the twenty motifs that have been produced from this research, the makers of batik cloth are involved to create new motifs from the eighty-six ornaments of pottery resulting from the research and to develop their own. The new motifs produced by the Banten batik cloth makers are also given names associated with the things they know about the Sultanate of Banten.

Naming the motifs after the Sultan or his family members and after names of the places closely associated with the reign of the Sultanate of Banten was the idea of the Banten batik community involved in the collaboration. The archaeologists collaborating with them did not attempt any intervention in this case. The choice of names associated with the Sultanate of Banten by the batik makers is not surprising. Marieke Bloembergen and Martijn Eickhoff (2015) in their research on the history of colonial and post-colonial heritage formation in Indonesia state that although in the past Banten was once under the VOC (the Duch East India Company) and then destroyed by the colonial rule under Daendels in the nineteenth century, the meaning of heritage in the Banten society today is strongly oriented to the greatness of the Banten Sultanate in trade and its Islamic traditions (Bloembergen and Eickhoff 2015: 146, 148). Violence that occurred during the colonial period was effectively marginalized (Bloembergen and Eikhoff 2015). This is evident, among others, in the Banten Museum display and at the Indonesian National Museum, which do not provide any information about the violence perpetuated by the colonial authorities including the burning of the palace in Banten. In addition, there is a desire from the Banten community who formed the Bantenology Foundation to reconstruct the palaces in Banten at the original sites so that they can be a symbol of the greatness of the Banten Sultanate (Bloembergen and Eickhoff 2015: 146-147). The places most visited by locals and tourists are the ancient mosque and the tombs of the Sultan of Banten, not the colonial relics such as the Dutch fortresses and tombs.

Thus, in addition to educating the community about the results of the pottery research and the motifs designed in this study, the research is also aimed at motivating the community to create new motifs in accordance with their wishes. Through the process of collaboration; the community are also made aware that through archaeological studies, today's society can 
gain benefits to improve their lives. As Richardson and Almansa-Sanchez point out, public archaeology involves the community positively and helps people to understand and value the archaeology profession and the results of archaeological research (Richardson and Almansa-Sanchez 2016: 204).

\section{FROM RUBBISH TO CULTURAL IDENTITY}

According to Mike Heyworth (2014), archaeology is one of the scientific disciplines to which one can contribute his or her knowledge in an original manner. This opportunity can be obtained through cooperative projects undertaken by the community that will benefit everyone (Heyworth 2014: 106).

After the collaboration with the Banten batik cloth maker community in 2014, an evaluation of the impact of this collaboration was conducted in 2018. Based on an interview with one of the Banten batik makers, namely Mr Uke from the Batik Banten Gallery, it was found that Banten batik has become one of the cultural identities of Banten. This is marked by the increasing number of visitors to the Batik Banten Gallery. In 2014, there were only one thousand visitors over a period of three months or four thousand people annually. Visitor data in 2018 show that the number of visitors from January to May was three thousand two hundred people or an estimated eight thousand people by the end of the year. Based on the data, the average growth rate of visits is eighteen percent per year. Apart from that, a governor's regulation was issued in 2014 on local content for high school that comprised the traditional martial arts of Banten: pencak silat, rampak bedug, and Banten batik. The impact of the governor's regulation is that Banten batik is now recognized as a part of the Banten cultural identity. Consequently, Banten batik is included in the high school curriculum as local content. Banten batik has also become a topic of study of theses and dissertations conducted by students from various universities. Banten batik has also been selected for the uniforms of government employees, starting with school teachers.

The material culture journey of the Banten pottery has thus come to a full circle. In the past, it was functional pottery that ended up as pottery shards, dumped as waste, and then excavated by archaeologists only to become a heap of rubbish at the Banten Museum site. During our collaborative process, this material rubbish was used as a source to learn about the intangible culture: the motifs that serve as a model for the Banten batik patterns. In turn, Banten batik is used as the cultural icon of Banten people today. This is the biography of Banten pottery.

The step from pottery to identity is related to the discovery of local characteristics that differentiate Banten from other regions. Batik is made all over Indonesia, and each region has its own unique color, style, and pattern. By discovering motifs that are grounded locally from their ancestors, the people in Banten can claim Banten batik as their very own.

In this case, by looking at differences, Banten Batik can be contrasted with batik from other places. The cultural identity of Banten is constructed through differences, namely characteristics that distinguish it from other batik 
fabrics that exist in almost all regions in Indonesia, through unique motives, namely the motif of pottery fragments that were once objects made by their own ancestors.

\section{ArChaEOLOGICAL RELEVANCE FOR THE PRESENT}

As stated by Barbara J. Little (2012), relating archaeology to current issues is to go beyond archaeology as a science and see how it can benefit society (Little 2012: 278-279). Little's assertion (2012) is reinforced by Selvakumar (2010) who asserts that talking about the relevance of archaeology means talking about archaeology that provides many benefits for today's society (2010:469). Likewise, Tilley (1989) asserts that archaeology does not stop at the discourse about the past but must be practically relevant to the present (in Selvakumar 2010: 478). The benefits of archaeology for education and science cannot be doubted but it can also be beneficial for solving the problems we all face in daily life. In this paper, archaeology, through the existence of archaeological sites, is shown to be able to provide economic benefits for the community.

Based on a study of the Batik Banten Gallery from an economic perspective, it is evident that there has been an increase in income since 2014. Gallery owners have received an increase in income of $20 \%$ per year so that in four years they gained an $80 \%$ revenue increase. Meanwhile, gallery employees, most of whom are school dropouts, have experienced a rise in income from Rp $1,200,000$ to $\operatorname{Rp} 2,000,000$, an increase of $66.6 \%$ per year. To meet the growing demand for Banten batik, the number of employees has also increased from 45 to 60 people. In addition to that, there has also been an increase in batik-making training provided by the Batik Banten Gallery. In 2014, only about 50 people were trained per month; however, in 2017 about 700 people were trained monthly. The trickle-down effect of the Banten batik industry experienced by the community around the Batik Banten Gallery is seen in the growing number of stalls selling a variety of daily commodities and car service stations. The most interesting effect is the increase in the price of land around the Gallery, which increased from Rp. 250,000 in 2014 to Rp. 2,000,000 in 2017 per square meter. Thus the future prospects of the Banten batik market are bright.

Material culture, in this case the shards of pottery, have been turned into ornaments or designs heritage of the people of Banten. The material culture from the past that has experienced a journey of changes in object value shows that this is an ongoing process. As stated by Elizabeth Crooke (2007: 309), the main nature of heritage is its fluidity. Using the rubbish theory, it can be concluded that there has been a change in the value of pottery objects that were originally part of the material culture of the Sultanate of Banten and then rediscovered in an archaeological excavation as rubbish. This then was turned into the Banten batik motif that was later established as the present Banten cultural identity. An important finding of this study is that the material culture of the past that is rediscovered through archaeological excavations can be useful to empower the present-day community and that it can also link today's community with the past. 


\section{CONCLUSION}

It is apparent that archaeological work today is no longer limited to the scope of archaeology as a science that is the monopoly of archaeologists. The postmodernist world demands that archaeology provides an access to knowledge for the public. Archaeology needs to focus more on developing its potentials and its relevance to today's society. Responding to this development, archaeology in Indonesia needs to move beyond the limits of routines that we have been creating over and over again. Archaeologists and archaeological practices should no longer be separated from the community but should become part of the community.

When observing archaeological practice using Thompson's rubbish theory (1979), we see how an object can travel from transient to rubbish and from rubbish to durable. This can be an inspiration for us in giving new meaning to the results of the research that we have done so far, so that they can become more relevant and useful for the community.

This article concretizes the durable aspect of the Thompson diagram to cultural identity. Then, there is one other aspect when cultural identity is the result of archaeological work, namely it has economic, social, and political functions. Another aspect is the fact that the process of implementing Thompson's diagram is participatory. Archaeologists facilitate its process and eventually the community themselves act in attaining their needs.

\section{REFERENCES}

Appadurai, Arjun. 1986. The social life of things. Cambridge: Cambridge University Press.

Bloembergen, Marieke and Martijn Eickhoff. 2015. "Re-embarking for Banten; The Sultanate that never really surrenderd", in: Marjet Derks, Martijn Eickhoff, Remco Ensel, and Floris Meens (eds), What's left behind; The Lieux de Mémoire of Europe beyond Europe, pp. 140-148. Nijmegen: Vantilt.

Carman, John. 2010. "Promotion to heritage; How museum objects are made", in: Monica Hagedorn-Saupe, Teijamari Jyrkkiö, Susanna Pettersson, and Astrid Weij, Encouraging collections mobility; a way forward for museums in Europe, pp. 74-85. Helsinki: Finnish National Gallery.

Crooke, Elizabeth. 2007. "The politics of heritage in Northern Ireland", in: Shiela Watson (ed.), Museum and their communities, pp. 300-312. London: Routledge.

Flatman, Joe. 2012. "Conclusion; The contemporary relevance of archaeology: Archaeology and the real world?", in: M. Rockman and J. Flatman (eds), Archaeology and society; Its relevance in the modern world, pp. 291-303. New York, NY: Springer.

González-Ruibal, Alfredo. 2014. An archaeology of resistance; Materiality and time in an African borderland. Lanham, MD: Rowman \& Littlefield.

Heyworth, Mike. 2014. “Archaeology for all”, Journal of Community Archaeology $\mathcal{E}$ Heritage 1(2): 105-106. 
Holtorf, Cornelius. 2007. Archaeology is a brand; The meaning of archaeology in contemporary popular culture. Walnut Creek, CA: Left Coast Press.

Howard, Peter. 2003. Heritage; Management, interpretation, identity. London/ New York: Continuum.

Kamus bahasa Indonesia. 2008. Kamus bahasa Indonesia. Jakarta: Pusat Bahasa, Departemen Pendidikan Nasional RI.

Kathirithamby-Wells, J. and J. Villiers (eds). 1990. The Southeast Asian port and polity; Rise and demise. Singapore: Singapore University Press.

Kopytoff, Igor. 1986. "The cultural biography of things; Commoditization as process", in: Arjun Appadurai, The social life of things: Commodities in cultural perspective, pp. 64-91. Cambridge: Cambridge University Press.

Lane, P.J. and B.B. Mapunda. 2004. Archaeology for whose interest-archaeologists or the locals? London: Routledge.

Leur, J. C. 1955. Indonesian trade and society; Essays in Asian social and economic history; Vol. 1. First edition. W. van Hoeve.

Little, Barbara J. 2012. "Envisioning engaged and useful archaeologies”, in: M. Rockman and J. Flatman (eds), Archaeology and society; Its relevance in the modern world, pp. 277-289. New York, NY: Springer.

Longhurst, Brian. 2008. Introducing cultural studies. Second edition. London: Routledge.

Marwoto-Johan, Irmawati. 2012a. “Archaeology for whose interpretation? Finding space for alternative archaeology in Indonesia", Public History Review 19: 111-119.

Marwoto-Johan, Irmawati. 2012b. “Ragam ornamen gerabah dari Kerajaan Banten di Situs Keraton Sorosowan". [Paper Seminar Sejarah Banten; Nilai-nilai sejarah sebagai fundamen pembangunan Banten. Dinas Budpar, Pemda Provisi Banten, 10-11 December.]

Matsuda, Akira 2016. "A consideration of public archaeology theories", Public Archaeology 15(1): 40-49.

Matsuda, Akira and Katsuyuki Okamura. 2011. "Introduction; New perspectives in global public archaeology", in: A. Matsuda and K. Okamura (eds), New perspectives in global public archaeology, pp. 1-18. New York, NY: Springer.

Mauss, Marcel. 1954. The gift; Forms and functions of exchange in archaic societies. Glencoe, Ill.: Free Press.

McDavid, Carol. 2004. "From 'traditional' archaeology to public archaeology to community action; The Levi Jordan Plantation Project", in: Paul A. Shackel and Erve J. Chambers (eds), Places in mind; Public archaeology as applied anthropology, pp. 41-62. London: Routledge.

McManamon, Francis P. and Alf Hatton (eds). 2000. Cultural resource management in contemporary society; Perspectives on managing and presenting the past. London/New York: Routledge.

Merriman, Nick (ed.). 2004. Public archaeology. London: Routledge.

Miller, Daniel. 2002. "Artefacts and the meaning of things", in: Tim Ingold (ed.), Companion encyclopedia of anthropology, pp. 396-419. London: Routledge. 
Mullins, Paul R. 2004. “African-American heritage in a multicultural community; An archaeology of race, culture, and consumption", in: Paul A. Shackel and Erve J. Chambers (eds), Places in mind; Public archaeology as applied anthropology, pp. 63-76. London: Routledge.

Parsons, Liz. 2007. “Thompson's rubbish theory; Exploring the practices of value creation", in: Stefania Borghini, Mary Ann McGrath, and Cele Otnes (eds), E- European advances in consumer research Vol. 8, pp. 390-393. Duluth, MN: Association for Consumer Research.

Pojoh, Ingrid H.E. 1981. "Pelandas Banten Lama; Sebuah penelitian pendahuluan teknologi tembikar". [Undergraduate thesis, Universitas Indonesia.]

Reid, Anthony. 1993. "Islamization and Christianization in Southeast Asia; The critical phase, 1550-1650", in: Anthony Reid (ed), Southeast Asia in the early modern era; Trade, power, and belief, pp. 151-179. Ithaca, NY: Cornell University Press.

Renfrew C, and Paul Bahn. 2000. Archaeology; Theories, methods and practise. London/New York: Thames \& Hudson.

Reno, Joshua. 2009. "Your trash is someone's treasurel; The politics of value at a Michigan landfill", Journal of Material Culture 14(1): 29-46.

Richardson, L-J. and J. Almansa-Sanchez. 2015. "Do you even know what public archaeology is? Trends, theory, practice, ethics", World Archaeology 47(2): 194-211.

Rudolfff, Britta. 2006. Intangible and tangible heritage; A topology of culture and contexts of faith. PhD thesis, Johannes Gutenberg University of Mainz.

Selvakumar, Veerasamy. 2010. "The use and relevance of archaeology in the post-modern world: Views from India", World Archaeology 42/3 (Archaeology and contempory society): 468-480.

Soegondho, Santoso. 1993. Wadah keramik tanah liat dari Gilimanuk dan Plawangan; Sebuah kajian teknologi dan fungsi. PhD thesis, Universitas Indonesia.

Sudjana, Wiwin Djuwita. 1978. “Gerabah Banten Lama; Suatu pengolahan data lapangan". [Undergraduate thesis, Universitas Indonesia.]

Sumadio, Bambang. 1990. Sejarah nasional Indonesia II. Jakarta: Balai Pustaka.

Syahril, Achmad. 1997. “Tembikar Sukadiri dan Panjunan dari situs Banten Lama; Identifikasi dan tinjauan persebaran". [Undergraduate thesis, Universitas Indonesia.]

Thompson, Michael. 1979. Rubbish theory. Oxford: Oxford University Press. Tilley, Christopher. 1989. "Archaeology as socio-political action in the present", in: Valerie Pinsky and Alison Wylie, Critical traditions in contemporary archaeology; Essays in the philosophy, history and socio-politics of archaeology, pp. 104-116. Cambridge: Cambridge University Press.

Trigger, Bruce G. 2006. A history of archaeological thought. Cambridge: Cambridge University Press.

Untoro, Heriyanti Ongkodharma. 1998. Perdagangan di Kesultanan Banten (1552-1684); Kajian arkeologi-ekonomi. PhD thesis, Universitas Indonesia. 
Untoro, Heriyanti Ongkodharma, Irmawati Marwoto, Isman Pratama Nasution, Dian Sulistyowati, Rizky Fardhyan, Mandala Manurung, Bambang Mahendratta Djaja, and Ghilman Assilmi. 2014. “Community Engagement Grants UI: Aplikasi ornamen gerabah Banten untuk motif Batik Banten; Upaya penguatan jati diri dan pemberdayaan masyarakat". Jakarta: Departemen Arkeologi, Fakultas Ilmu Pengetahuan Budaya Universitas Indonesia. [Reprint.]

Warner, Mark S. and Daryl Baldwin. 2004. "Miami nation and archaeology", in: Paul A. Shackel and Erve J. Chambers (eds), Places in mind; Public archaeology as applied anthropology, pp. 137-151. London/New York: Routledge. 
ApPENDIX $^{1}$

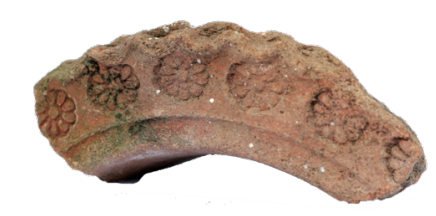

$1 \mathrm{a}$

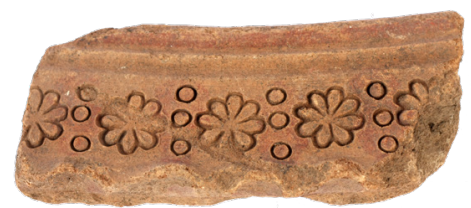

$2 \mathrm{a}$

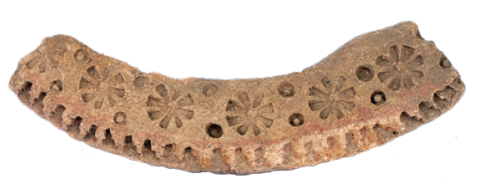

$3 a$

$4 a$

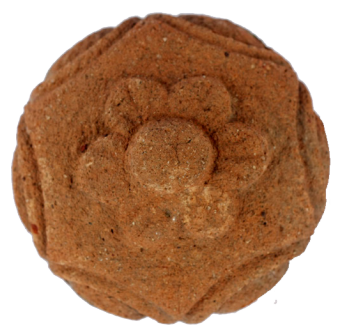

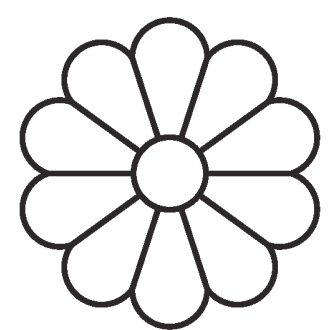
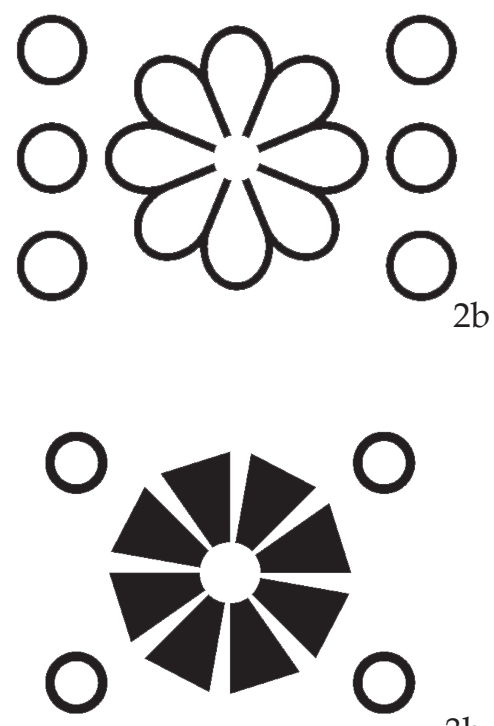

$3 b$

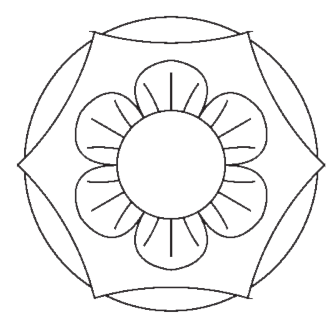

$4 b$ 

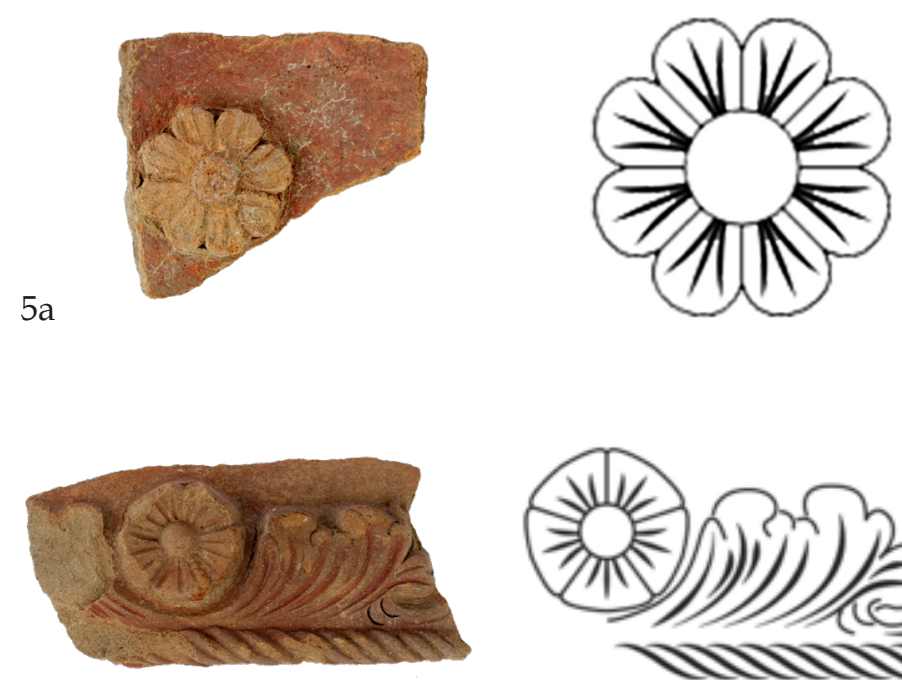

$6 a$
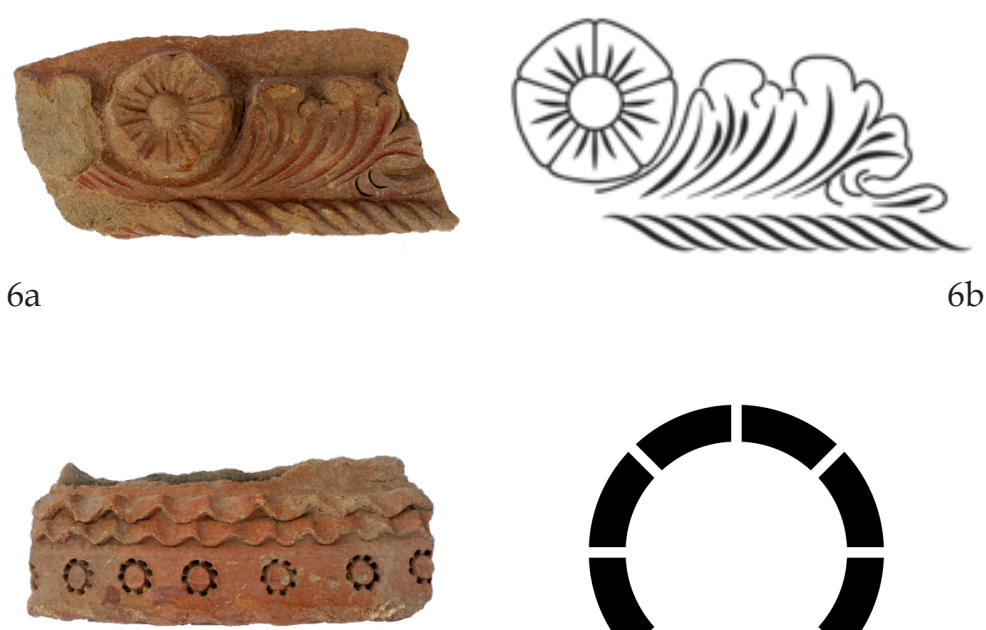

$7 a$

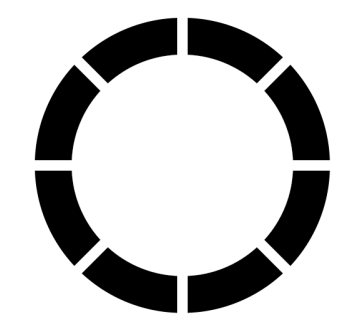

$7 b$
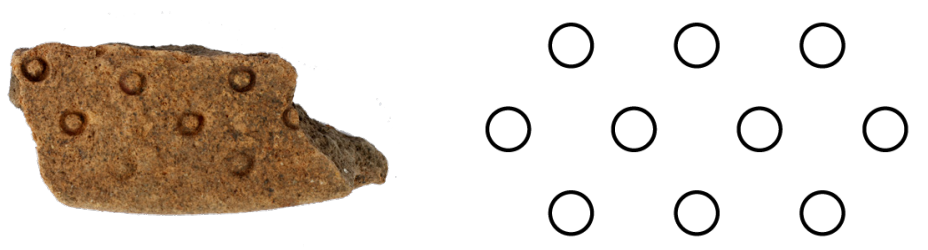

$8 a$
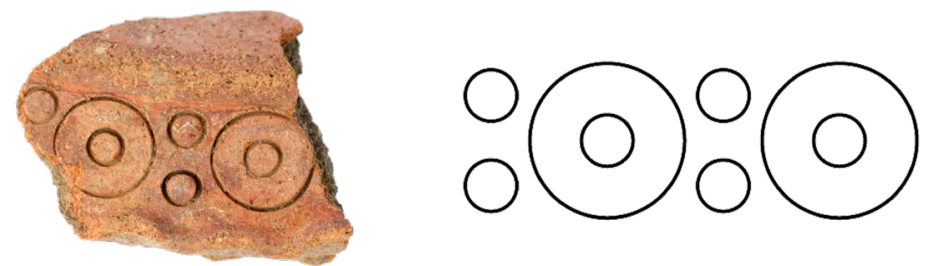

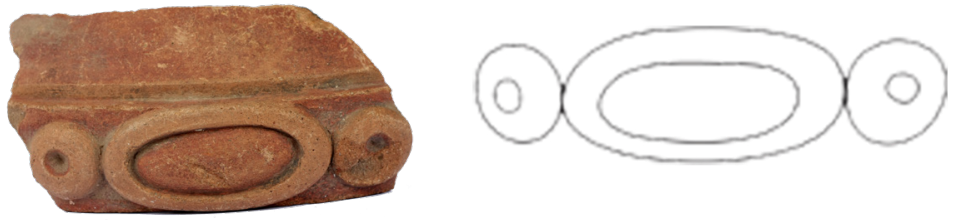

$10 a$
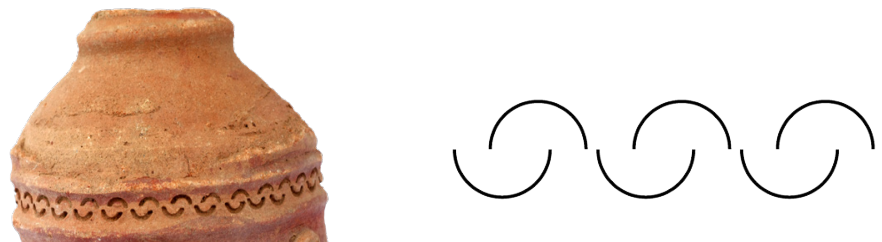

$12 a$
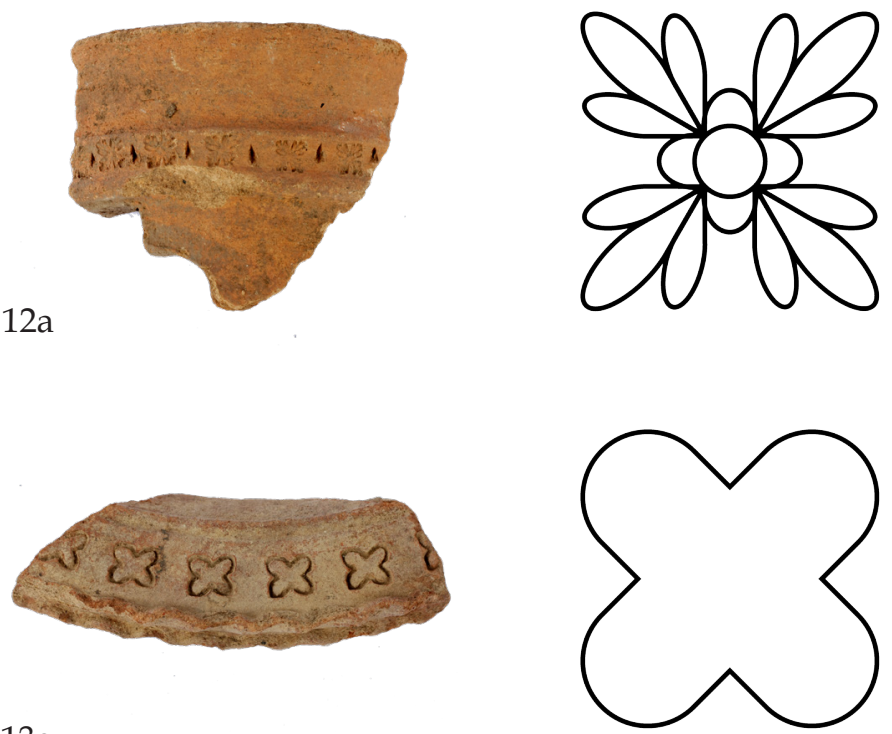

$13 a$
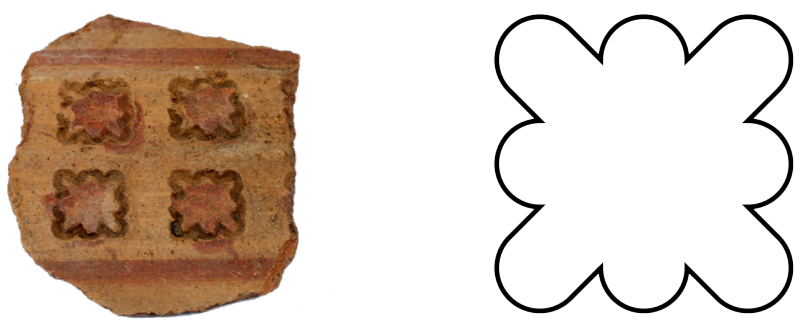

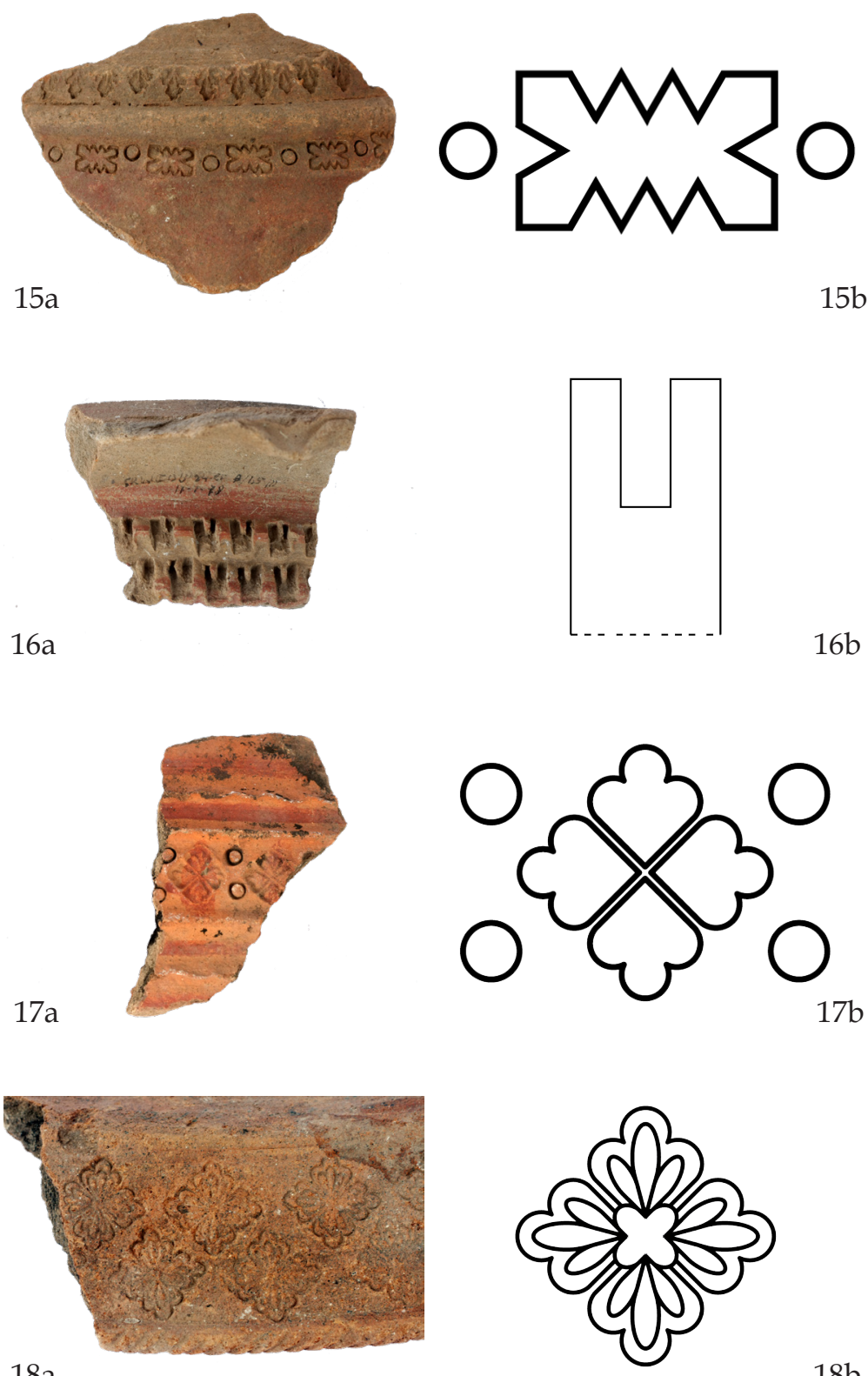

$18 a$

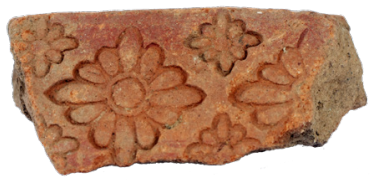

$19 \mathrm{a}$

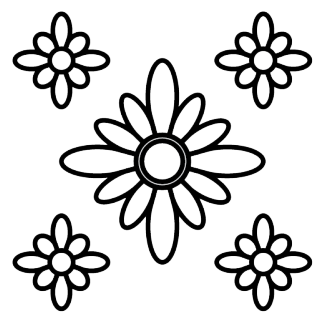



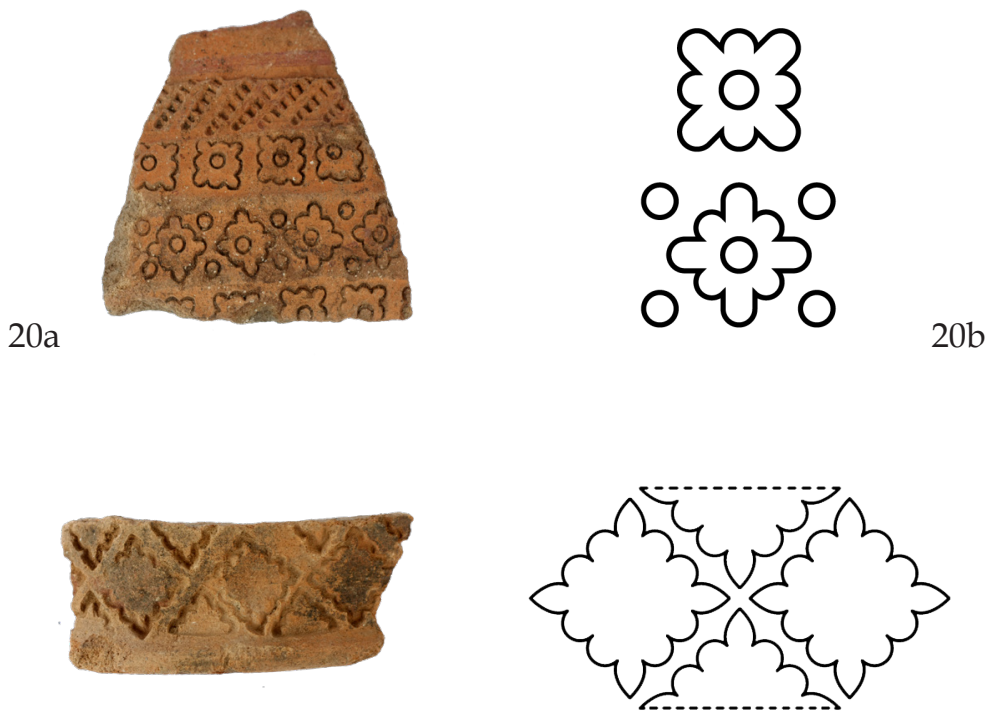

$21 \mathrm{a}$
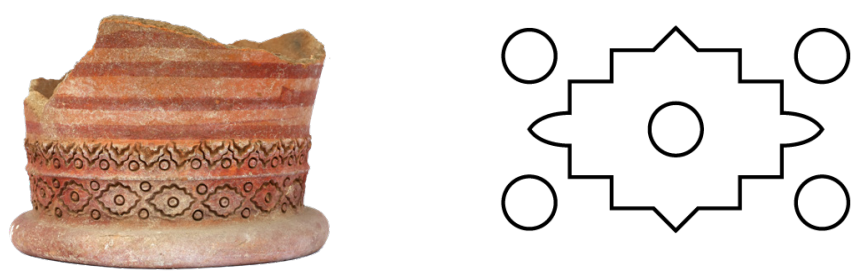

$22 a$
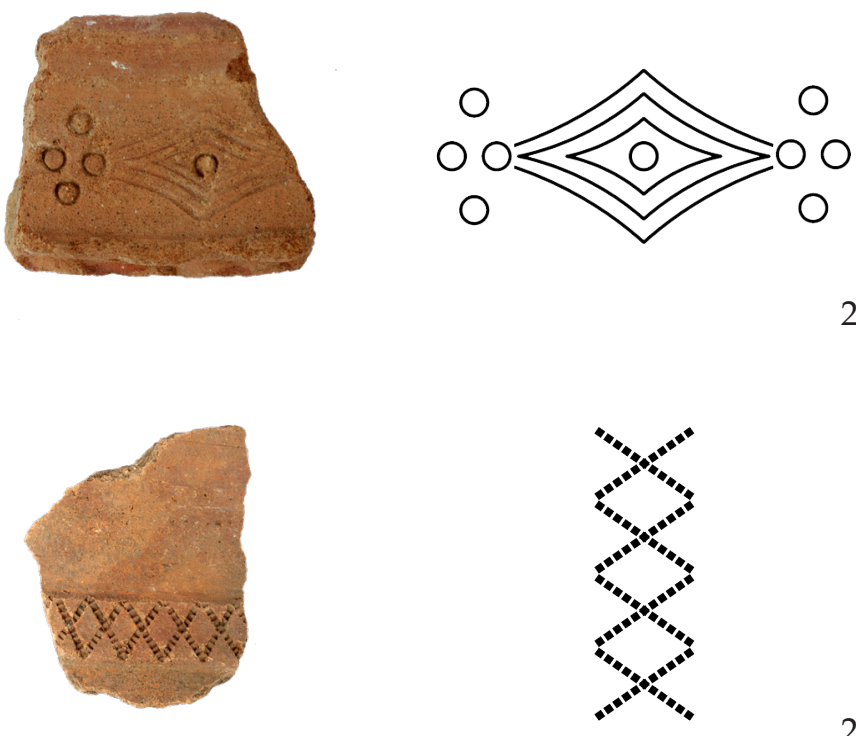

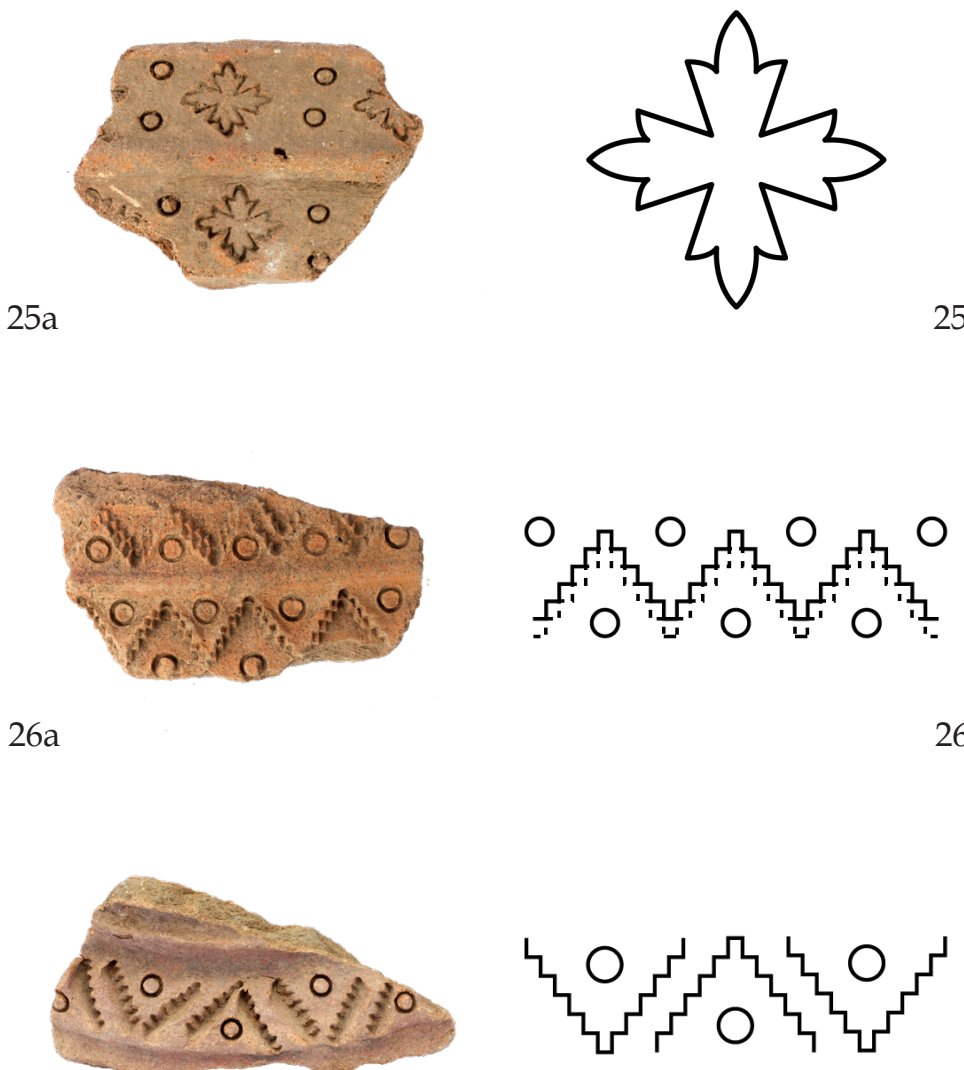

$27 a$

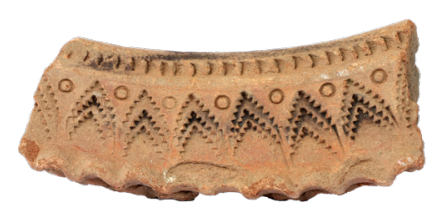

$28 \mathrm{a}$
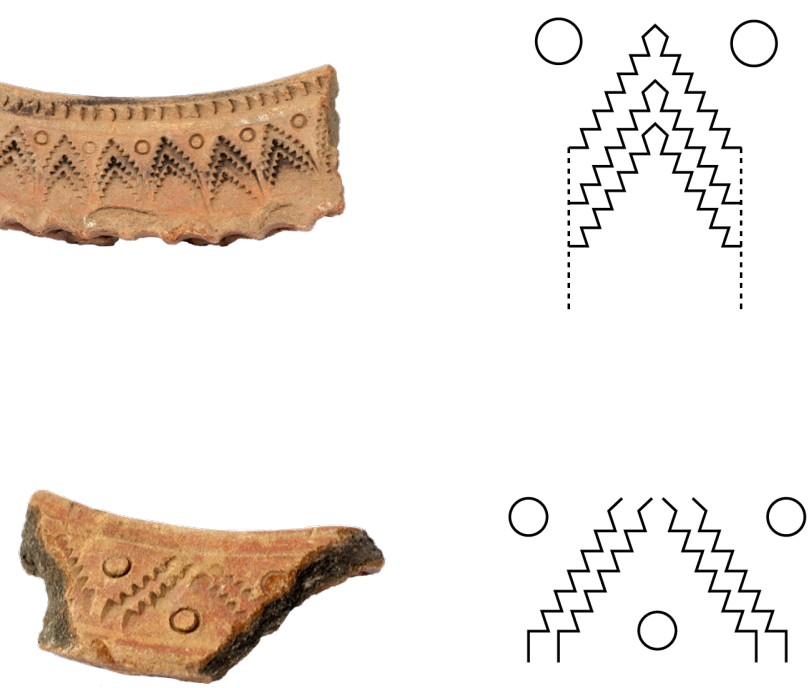

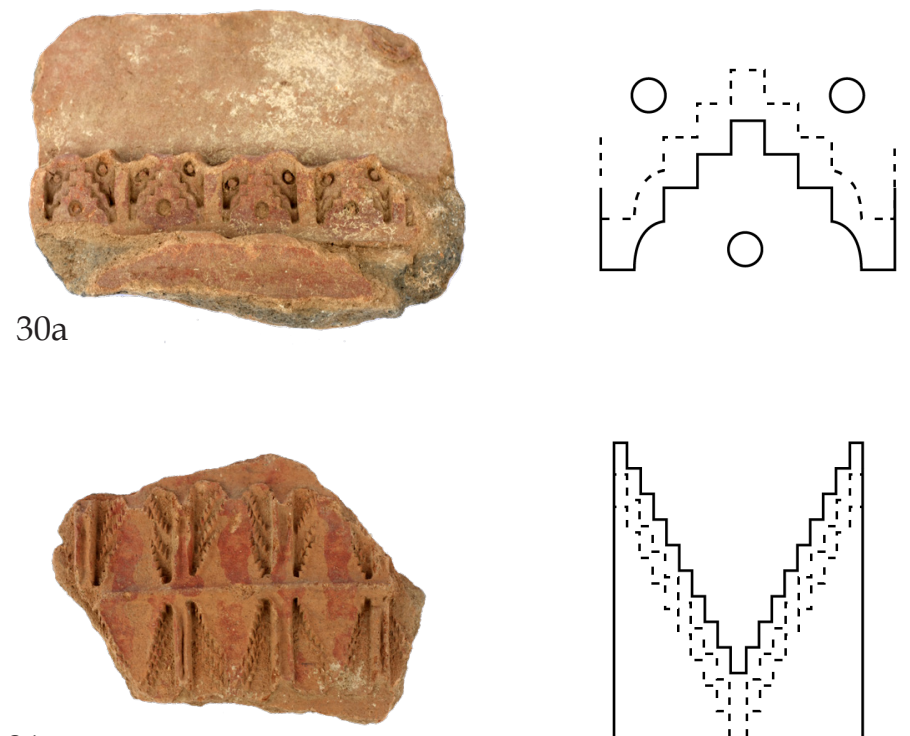

$31 \mathrm{a}$

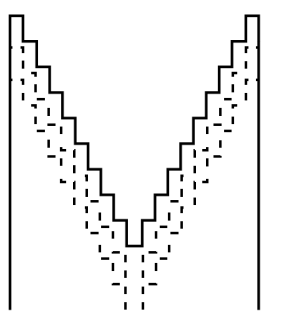

$31 b$
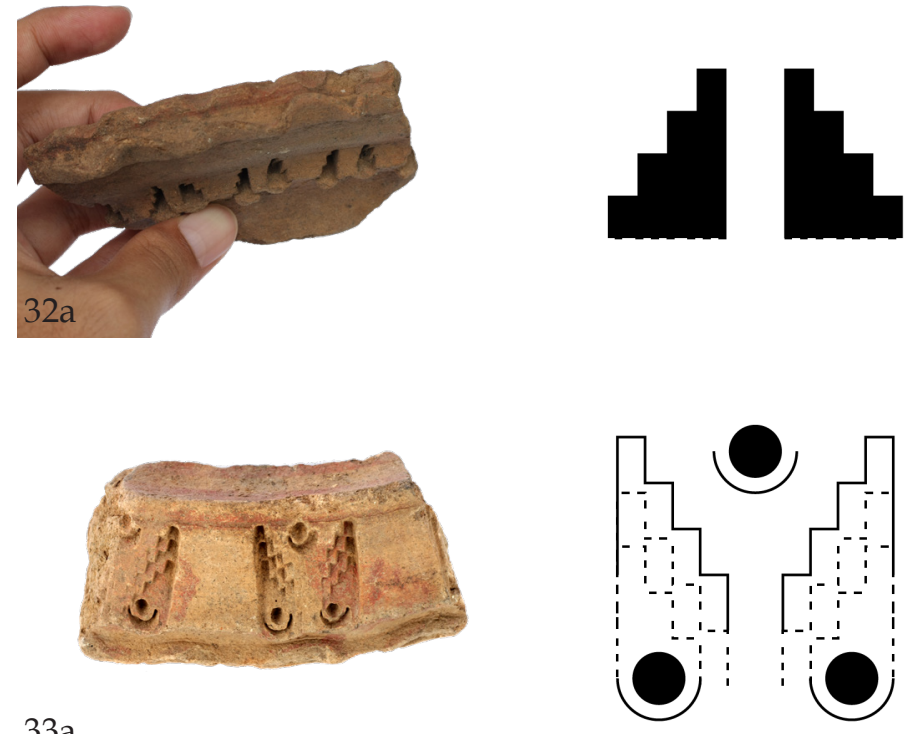

$33 a$
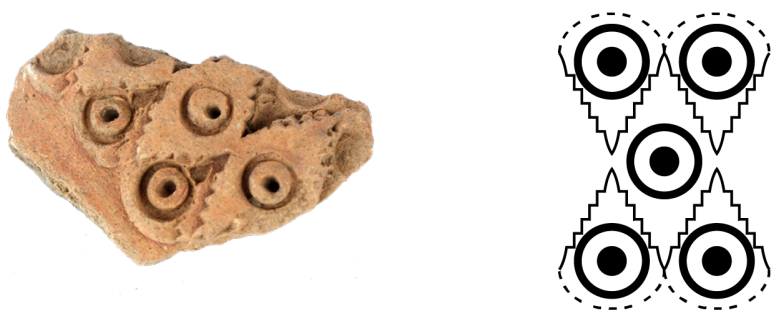

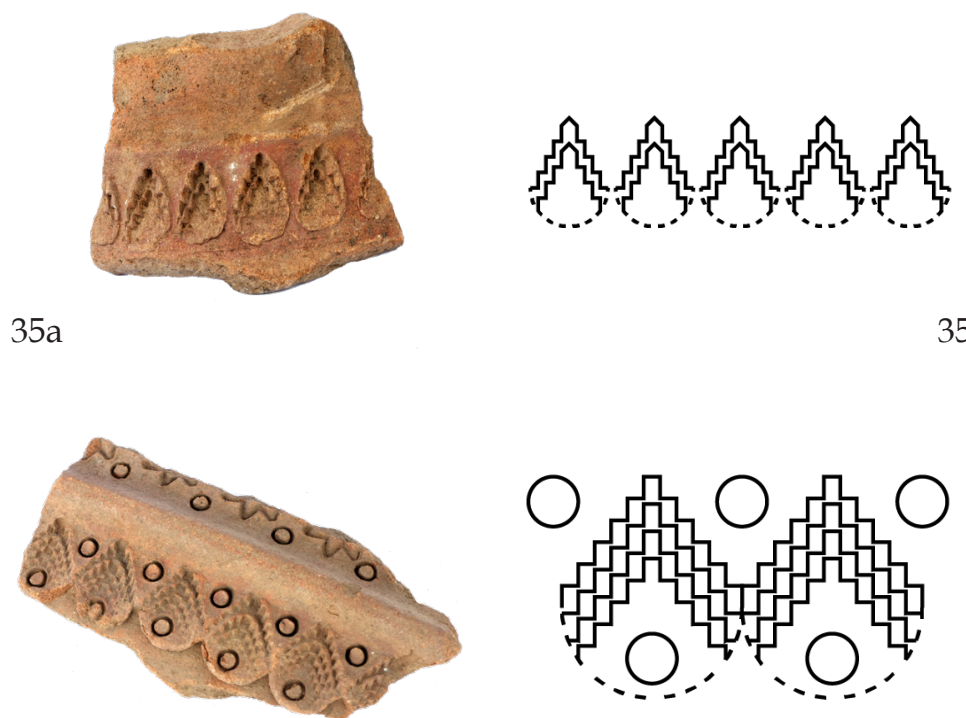

$36 a$
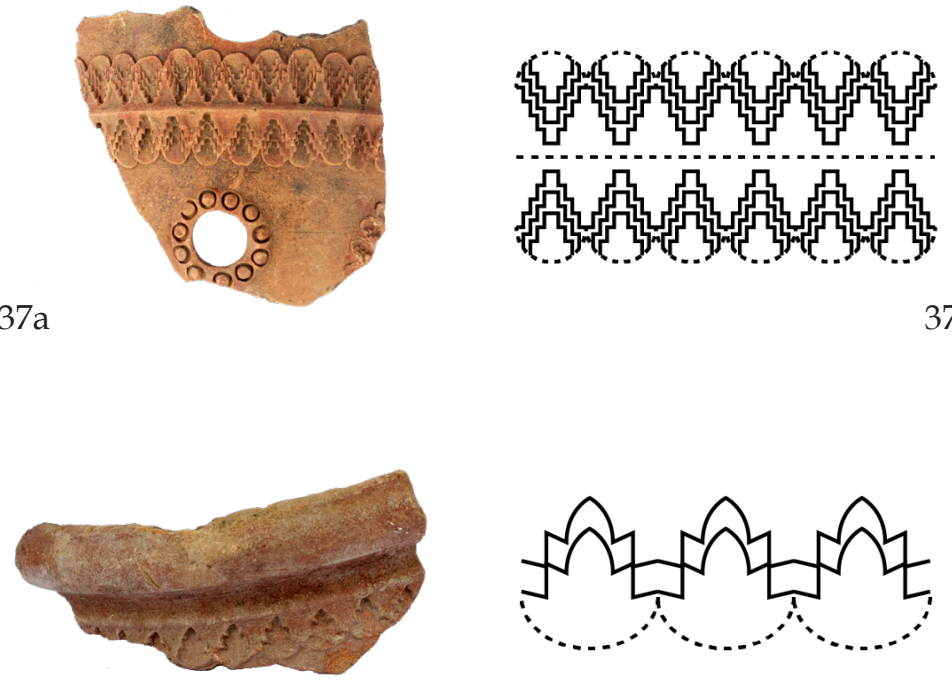

$38 \mathrm{a}$
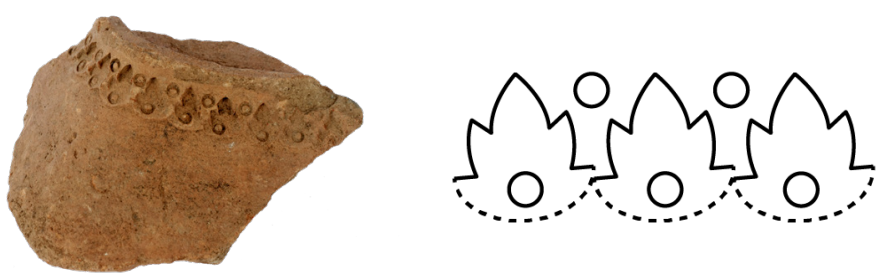


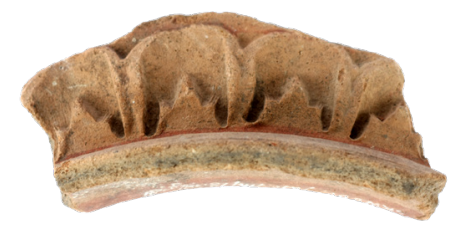

$40 a$

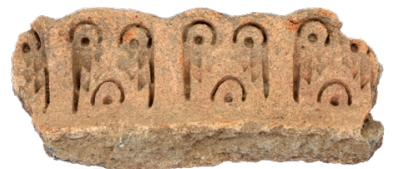

$41 a$

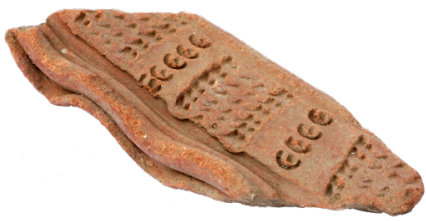

$42 \mathrm{a}$

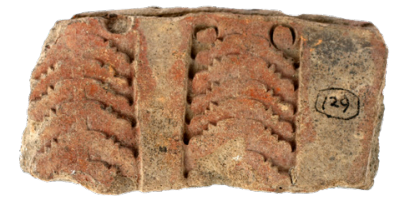

$43 a$

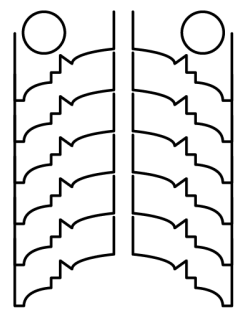

$43 b$

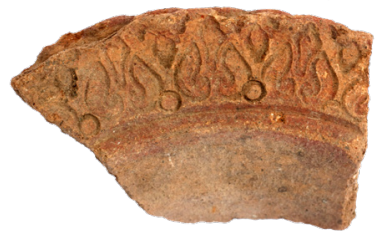

की 

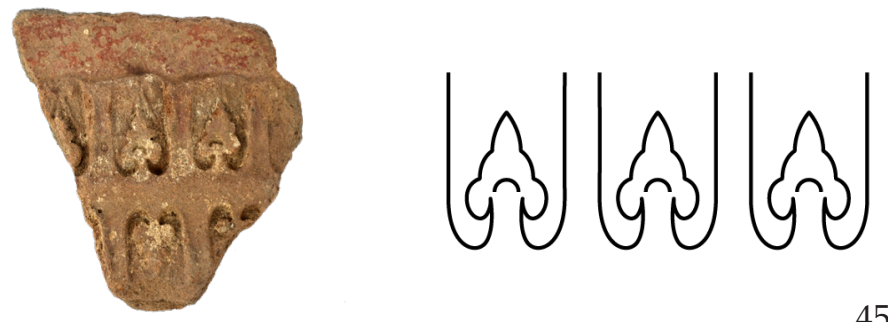

$45 a$

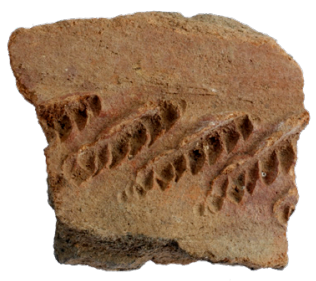

$46 a$

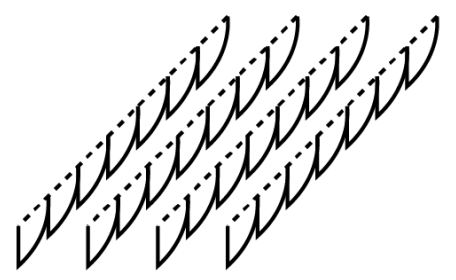

$46 b$

$47 \mathrm{a}$
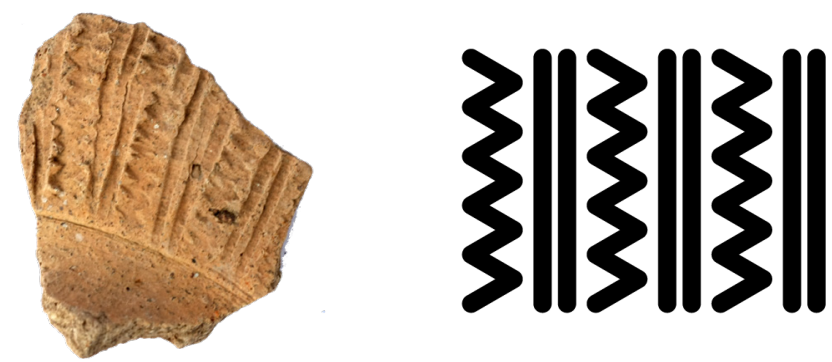

$47 b$
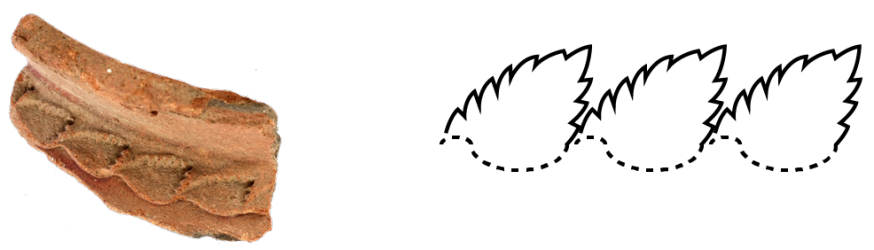

$48 a$
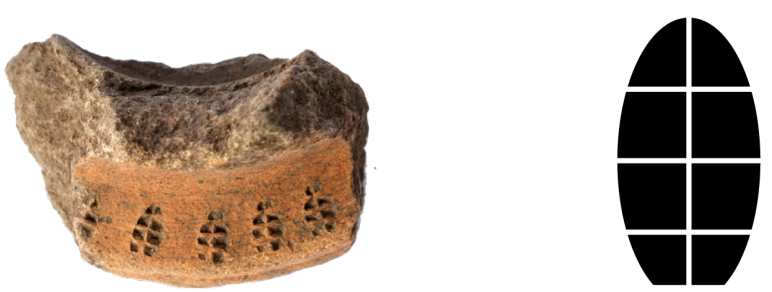


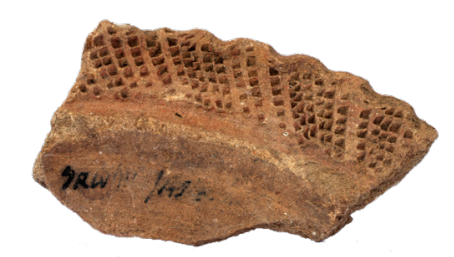

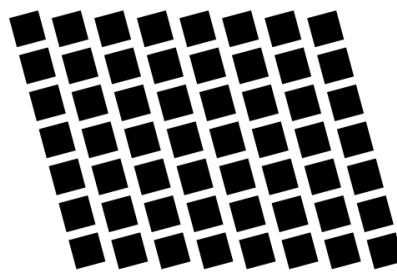

$50 a$
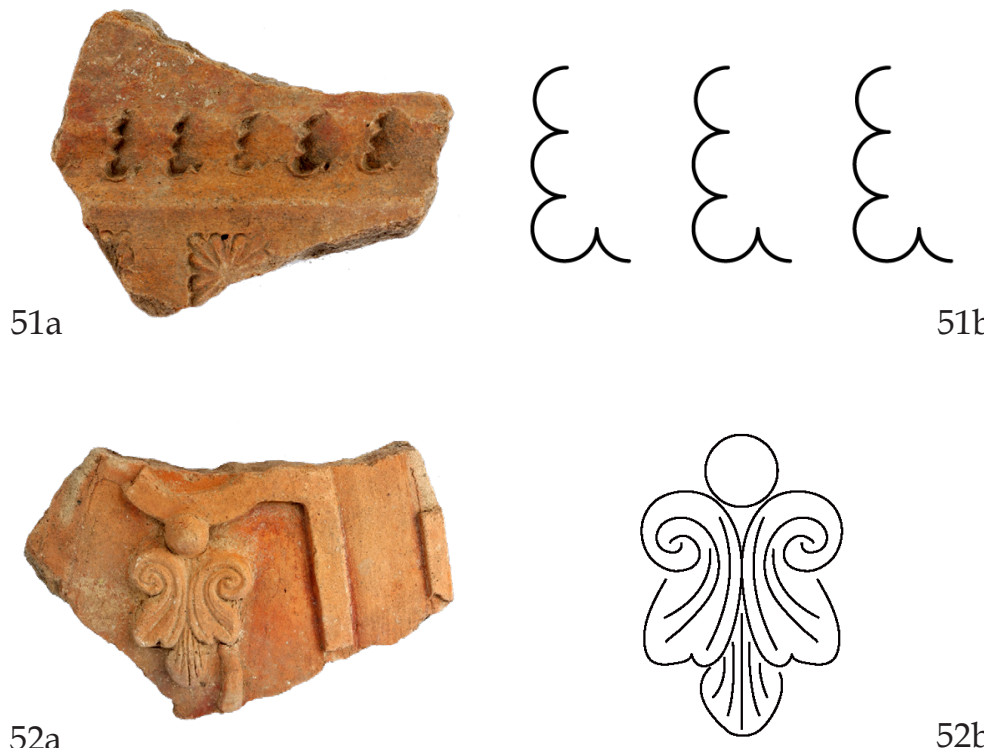

$52 b$
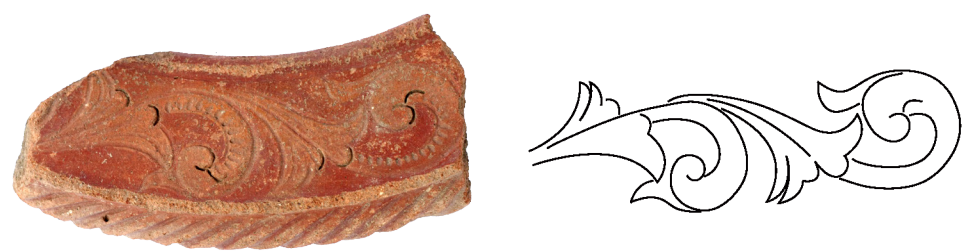

$53 a$
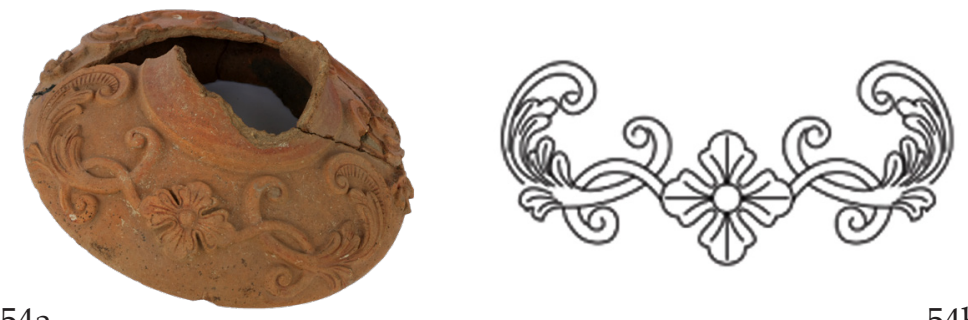

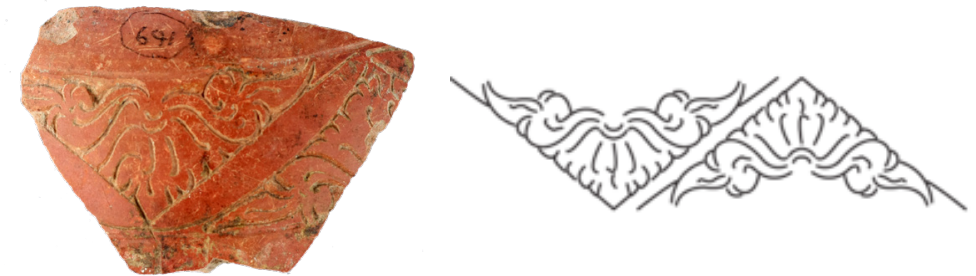

$55 a$

$55 b$

$56 a$
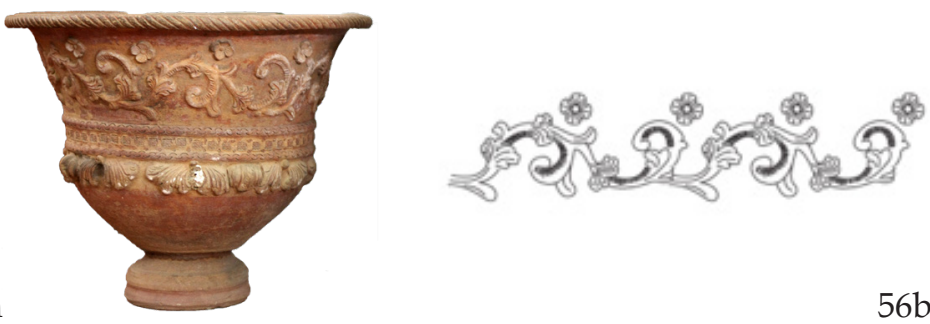

$57^{2}$

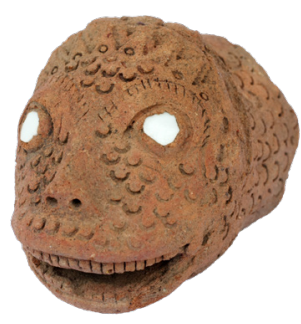

$56 b$

58

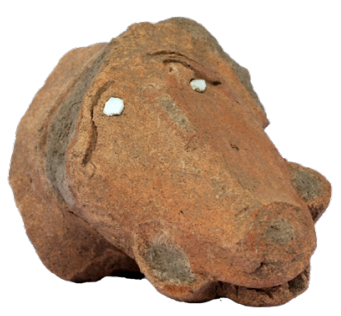

2 At this stage of the research, the designs in the form of animal and human figures (57-63, 66-67) have not yet been studied in depth. 

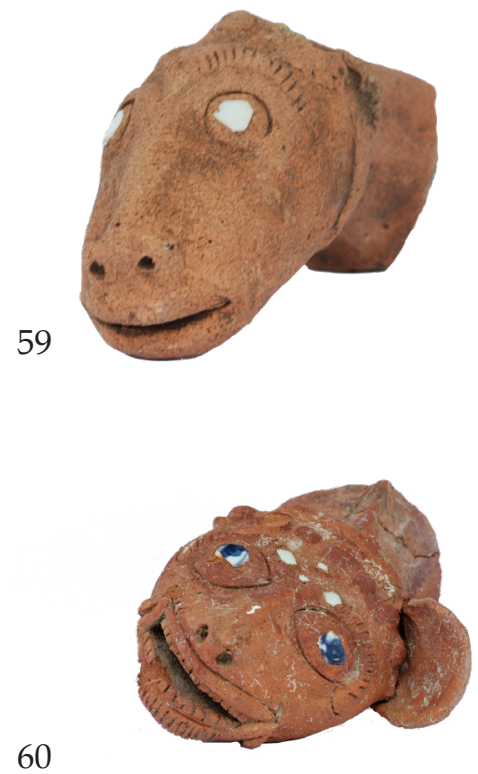

61
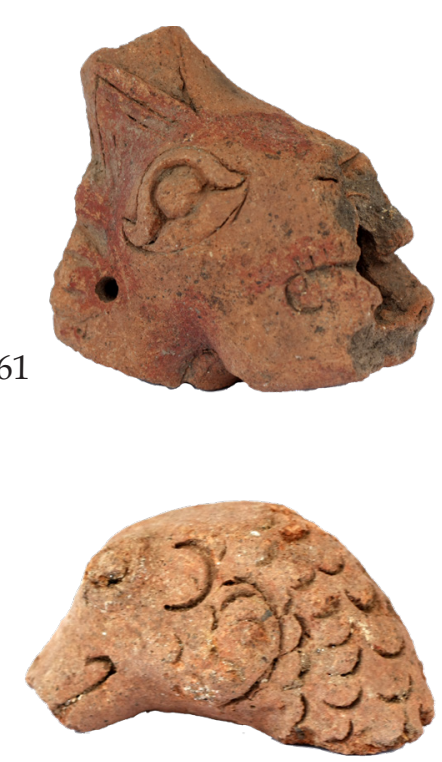

62

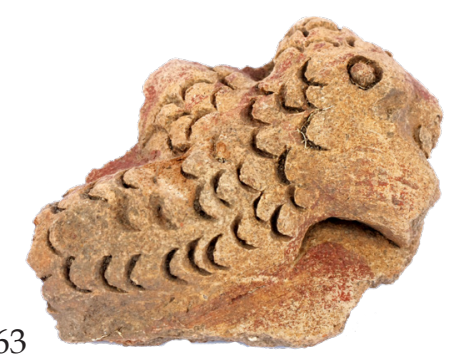



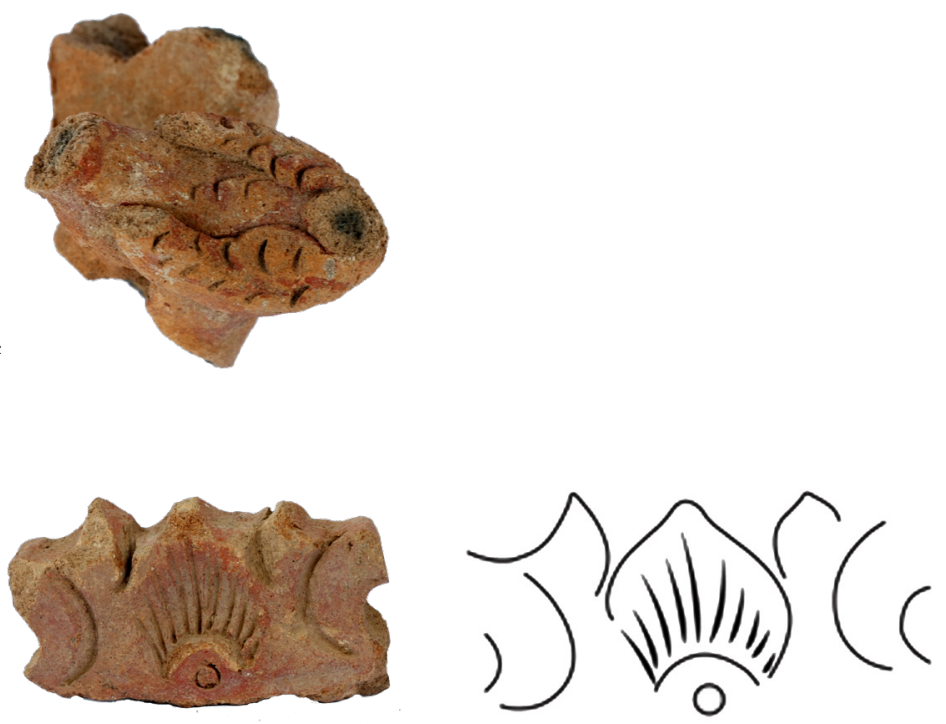

$65 a$

$65 b$

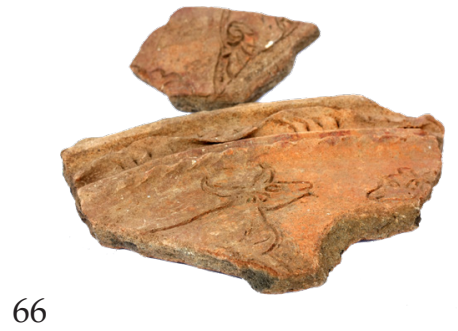

67

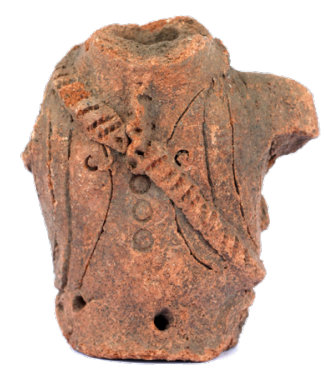

